\title{
The Impossible Republic: The Reconquest of Algeria and the Decolonization of France, 1945-1962*
}

\author{
James McDougall \\ University of Oxford
}

In December 1960, Le Progrès, a regional newspaper published in southeastern France, carried a story about the ceremonial inauguration of a "new village" in the region of Oran in northwestern Algeria. Previously referred to as "El Ouennane number 3," the settlement was now named the "village de l'Ain," after the rural département of metropolitan France, located between Lyon and the Swiss border, that had substantially financed its construction by public subscription. According to the report, twenty-two million old francs - or 220,000 new francs, since the currency reform of January 1960 - had been raised by contributors to pay for new two- and three-room houses in which five hundred Algerians were to be resettled. In officially opening the village, Jean Saint-Cyr, the president of the conseil-général of the donor département and head of the twinning committee responsible for the newly affirmed links between the foothills of the Jura and the western Algerian plains country, addressed Jean Morin, the Republic's délégué général (the new title for the head of the colonial government in Algeria) on behalf of his metropolitan constituents: "We follow every day with intense interest the unfolding of the events that have marked the course of the Algerian drama. We know that history provides few examples of missions as difficult as that entrusted to General De Gaulle. We should be very happy if, tomorrow, it should prove that the département of the Ain has been able to bring its own small contribution to the generous and humane work to which, monsieur le Délégué général, you have so fortunately devoted yourself, in the service of France and Algeria." Replying, Morin declared that the day's event marked "a victory of solidarity and fraternity for those who live on either side of the Mediterranean. . . . Here, in this part of Algeria, we have thought for man and with

* I am grateful to participants in the "Reconsidering Colonialism" workshop in Cambridge and the global and imperial history seminar in Oxford, and especially to Claire Marynower, Emile Chabal, Neil MacMaster, and the journal's anonymous reviewers, for comments on much earlier versions of this article. Archival sources referred to are held in France at the Centre des archives diplomatiques, Nantes (FR/CADN), the Archives nationales d'Outre Mer, Aix-en-Provence (FR/ANOM), the former Centre des archives contemporaines, Fontainebleau (FR/CAC), and in Algeria at the Algerian National Archives, Birkhadem (Algiers) (DZ/AN).

The Journal of Modern History 89 (December 2017): 772-811

(C) 2017 by The University of Chicago. 0022-2801/2017/8904-0002\$10.00

All rights reserved. 
him; in building this village, you have desired to show how firmly, in the metropole, we believe in the indissolubility of the ties that join us with Algeria."

This episode might appear to be nothing more than a fait divers, a merely ironic anecdote, if a particularly striking instance of the very belated policy of "integrating" war-torn Algeria into the French republican body politic. These words were spoken by high-ranking officials of the state, these ceremonies reported, at precisely the time that we might conventionally consider the final disengagement of France from Algeria to have begun, in the endgame of the vicious war of independence that had raged there for six years. De Gaulle's watershed speech evoking the future existence of "an Algérie algérienne... an Algerian republic" had already been made on November 4, 1960; mass demonstrations in Algerian cities in support of the revolutionary Front de Libération Nationale (FLN), marking the decisive turning point of public, popular adhesion to the cause of independence, would occur on December 11, the week after this story was filed. ${ }^{2}$ At the same time, between December 9 and 11, De Gaulle, visiting Algeria, would be the target of four failed or aborted assassination attempts by the colonialist "ultras" of the Front pour l'Algérie Française (FAF, the forerunner of the Organisation de l'Armée Secrète, or OAS), signaling the beginning of the disintegration of the French effort in Algeria into an intraFrench near-civil war. ${ }^{3}$ Two weeks later (December 19), the UN General Assembly would pass a resolution calling for self-determination for Algeria and respect for its territorial integrity; a referendum on self-determination would in fact take place the following month, on January 8, 1961. Georges Pompidou, representing De Gaulle, would meet Ahmad Boumendjel, a leading Algerian lawyer and member of the FLN, in February, and the first (though abortive) announcement of negotiations between the government of France and the FLN's provisional government-in-exile, the GPRA, would be made at the end of March. So what was going on at the new little "village de l'Ain," this material expression of "the

1 “Un nouveau douar est né. ..," Le Progrès (Bourg-en-Bresse), December 5, 1960; clipping in FR/CADN/Alg/Amb(DG)/51/2. The title still exists today.

${ }^{2}$ Charles de Gaulle, Discours et messages, 5 vols. (Paris, 1970-71), 4:256-62, 258, 259. The Front de Libération Nationale, whose existence was announced in its declaration of war aims on November 1, 1954, was initially made up of radical former members of the PPA-MTLD (the clandestine Parti du peuple algérien, founded in 1937 but banned since 1939, and its legal cover the Mouvement pour le triomphe des libertés démocratiques, founded in 1946), the leading and most militant Algerian nationalist organization, which had been embroiled in an internal factional crisis since 1952.

${ }^{3}$ The Front pour l'Algérie Française was created in 1960 as a successor to the Organisation de Résistance de l'Algérie française, created in Algiers in 1956, and the Front National Français, established in November 1958. The Organisation de l'Armée Secrète, founded in Madrid in early 1961, comprised colonialist "ultra" armed groups set up to resist Algerian decolonization by force of arms. 
indissolubility of the ties" that, by "generous and humane work," were so concretely affirming Algeria's place within the trans-Mediterranean French Republic - and was it anything more than a very bad joke?

Much recent scholarship on the colonial state and decolonization in the French empire, and in relation to Algeria in particular, has focused both on the military aspects of war and counterinsurgency (and especially on torture) and on the simultaneous unfolding of late colonial reform, antiracism, and the origins of the developmentalist state. In respect of the former, some historians have perhaps too simply stressed the practice of violence as a monochrome history of total victimization practiced by a "militarized colonial state," "a terror matrix with torture at its core." In respect of the latter, others have perhaps conversely been too ready to accept the claims of late colonial reform as having credibly attempted, until the last moment, "to make real the principles of . . . equality and ... universality" that the imperial Republic had always claimed to embody, only to abandon those ideals at the eleventh hour. ${ }^{6}$ While both developmental reform and repressive violence were often central to late colonialism (often, of course, as the conjoined twins of counterinsurgency), the logic of events in Algeria, as strikingly illustrated by the tragicomedy of

\footnotetext{
${ }^{4}$ Marnia Lazreg, Torture and the Twilight of Empire: From Algiers to Baghdad (Princeton, NJ, 2008), 3, 60.

${ }^{5}$ Todd Shepard, The Invention of Decolonization: The Algerian War and the Remaking of France (Ithaca, NY, 2006), 15.

${ }^{6}$ For the policy reorientations of the "late colonial state" more generally, see Martin Shipway, Decolonisation and Its Impact: A Comparative Approach to the End of the Colonial Empires (Oxford, 2008), and chap. 6 on warfare; on the limits and reinventions of imperial systems both before and after World War II, see Frederick Cooper, Decolonization and African Societv: The Labor Ouestion in French and British Africa (Cambridge, 1996), Colonialism in Question: Theory, Knowledge, History (Berkeley, CA, 2001), chaps. 6 and 7, and Citizenship between Empire and Nation: Remaking France and French Africa, 1945-1960 (Princeton, NJ, 2014). On the expansive "affirmative action" programs for French citizens of indigenous (Muslim) Algerian origin in the first years of the Fifth Republic, and their eventual abandonment, see Shepard, Invention of Decolonization. For the colonial state as essentially violent, see Lazreg, Torture and the Twilight of Empire; see also Abdelmajid Hannoum, Violent Modernity: France in Algeria (Cambridge, MA, 2012); and, more subtly, Benjamin C. Brower, A Desert Named Peace: The Violence of France's Empire in the Algerian Sahara, 1844-1902 (New York, 2009). For critiques of some of the literature on violence, see reviews of Lazreg by Raphälle Branche, H-France Review 8 (August 2008): 367-70; and James McDougall, American Historical Review 114, no. 4 (2009): 1025-27. For other work explicitly addressing both violence and reformism, see Joshua Cole, "Remembering the Battle of Paris: 17 October 1961 in French and Algerian Memory," French Politics. Culture and Societv 21, no. 3 (2003): 21-50; James House and Neil MacMaster, Paris 1961: Algerians, State Terror, and Memory (Oxford, 2006); Alain Dewerpe, Charonne 8 février 1962: Anthropologie historique d'un massacre d'État (Paris, 2006).
} 
El Ouennane in 1960, provides a particularly stark case of the extremes to which each, together, could be taken.

To use an appropriately French distinction between the pays légal and the pays réel, what seems to have happened in Algeria is that as the formal regime of the reformist empire became more overtly inclusive in the postwar context, so the real regime of reasserted colonialism became more unaccountably repressive. Both tendencies would culminate, and combine, in the later stages of the "total" counterinsurgency war whose climax was reached between 1958 and 1962, when Algerians both became formally fully enfranchised citizens and at the same time were exposed to a regime of unmitigated emergency powers that outdid, in both its legal and, especially, its extrajudicial violence, the legalized "exceptional" repression to which they had previously been subject."

This logic of events can be seen to have worked itself out over two phases. First, from 1945 up to the escalation of the Algerian crisis in the late 1950s, what was at stake across the French empire was the normalization of France's colonial "empire of law." "The normalization of rule in place of what had hitherto been thought of (despite their longevity) as transitory, "emergency" forms of governance - by decree, by local administrators' prerogative, and by institutionalized "exceptional" provisions under the so-called régime(s) de l'indigénat, or "native-status" regulations - was necessary, it seemed, to fulfill the longpromised vision of a multiracial, transcontinental French Republic born of its

${ }^{7}$ It is impossible to quantify the toll of repression during the war, but it is clear that, particularly from 1957, both judicial and extrajudicial violence reached a peak that surpassed anything seen in Algeria since the "pacification" of the nineteenth century (though without coming close to the latter in the rate of mortality inflicted). In 1957 alone, almost four hundred Algerians were sentenced to death; over the course of the war, at least one and half thousand death sentences were pronounced (214 per year), of which at least some two hundred, or 28 each year, were carried out. (The available statistics are incomplete: see Sylvie Thénault, Une drôle de justice: Les magistrats dans la guerre d'Algérie [Paris, 2001], 89, 313-14.) Overall, the most careful estimates suggest that between 150,000 and 215,000 Algerians, in arms or not, were killed by French action in 1954-62. Very many more, certainly numbered in the millions, were imprisoned, detained, injured, or subjected to confiscation and destruction of property, forcible resettlement, and so on. Rape was widespread but it is impossible to estimate how many women were subjected to it. Similarly prudent estimates reckon the casualties of the repression of May-June 1945 - almost entirely civilians - at between six and eight thousand. See Guy Pervillé, "La guerre d'Algérie: Combien de morts?," in La guerre d'Algérie, 1954-2004: La fin de l'amnésie?, ed. Mohammed Harbi and Gilbert Meynier (Paris, 2004), 477-93.

${ }^{8}$ Emmanuelle Saada, "The Empire of Law: Dignity, Prestige and Domination in the 'Colonial Situation,'” French Politics. Culture and Societv 20, no. 2 (2002), 98-120, cf. Gregory Mann, "What Was the Indigénat? The 'Empire of Law' in French West Africa," Journal of African History 50, no. 3 (2009): 331-53. 
nineteenth-century imperial origins but, after 1945 , transcending them. ${ }^{9}$ This was necessary across the colonial empire, but it was both especially urgent and especially problematic in the settler-colonial Algerian départements. West African workers and politicians were already making unsustainable demands on welfare budgets and parliamentary representation that made metropolitans fear the republican ship would be "swamped" by its clamorous dependents. ${ }^{10}$ But reinventing an equal, trans-Mediterranean republic shorn of its colonial dimensions, a project nowhere more strikingly, materially illustrated than at El-Ouennane/l'Ain, proved an impossible undertaking - and not only because, as became apparent in West and Central Africa, it proved prohibitively expensive, nor simply because settler and metropolitan racisms and burgeoning anticolonial nationalisms rejected it. Realizing the dream of an integrative, "Eurafrican" republic was also fundamentally impossible because, as the "normalized" rule of law replaced the expediency of earlier régimes d'exception and the realm of citizenship expanded, the determination of settler-colonial politics to maintain minority rule and that of the administration to impose "security" by repressing nationalist demands combined to stall and subvert the reform process. Long before the outbreak of the war in Algeria in November 1954, large-scale extralegal repression-electoral fraud, intimidation, torture, and extrajudicial killing — began to replace the "ordinary" legal violence that no longer kept colonial subjects in check.

This was not simply a matter of inclusive ideology outdone by the brute facts of repression on the ground. Rather, a range of ideological positions among French settlers, soldiers, politicians, and technocrats, while varying in perspective and emphasis, essentially converged on the aims, the means, and the neces-

${ }^{9}$ While it is often referred to in the literature as a code, the indigénat regime was not a body of law but a congeries of repressive practices whose common features were a lack of due process and the fact that only noncitizen indigènes (natives) were subject to them. Seeking to regulate these practices more firmly, the colonial government sought to codify them, most prominently in the law of June 28,1881 , that enabled rural commune mixte administrators in Algeria to inflict fines or imprisonment for infractions, proven or suspected, "particular to the indigénat," that is, committed by noncitizen Algerians (and not usually punishable under regular criminal law). Higher authorities - prefects and the governor-general - retained other, more sweeping powers, for example, to order exile or indefinite house arrest, and no single legal text ever formalized the full extent of the repressive system. But the local administrators' disciplinary powers under the 1881 law came to sum up and symbolize the indigénat for those subjected to it. Similar systems were enacted in Indochina in 1881 and in Senegal in 1887. See Isabelle Merle, "De la 'légalisation' de la violence en contexte colonial: Le régime de l'indigénat en question," Politix 17/66 (2004): 137-62, and Sylvie Thénault, Violences ordinaires en Algérie coloniale: Camps, internements, assignations à résidence (Paris, 2012). On the routinization of "exception" and the abuse of power, see Didier Guignard, L'abus de pouvoir dans l'Aleérie coloniale (Nanterre, 2010).

${ }^{10}$ For West Africa, see especially Cooper, Decolonization and African Society, and Citizenship between Empire and Nation. 
sity of keeping Algeria within the French orbit. It was the changing political and institutional conditions brought about by the postwar agenda for colonial reform and renewal that, in this first phase, drove colonial settlers and administrators to block reform wherever possible and to subvert its anticipated effects wherever necessary, producing a spiral of extralegal repression that voided citizenship of its substance and pushed ever more Algerians into a radicalized, insurrectionary nationalism. In 1945, the vision of a revolutionary armed struggle was a minority position among Algerian nationalists, a ruinous prospect that most still wished to avoid; a decade later it imposed itself even on moderates as the only available course of action.

In a second phase, on his return to power after May 1958, De Gaulle stepped up both the reform agenda and the war effort in response to the deepening crisis brought on by Algerians' resort to arms, the subversive potential of settlers and soldiers in Algeria, and the combined destabilizing effects of both on the French state itself. Between 1958 and 1961, the de jure "integration" of Algeria and all its inhabitants into the renewed republican body politic reached its fullest extent. But now, implementing the newfound determination to make Algeria truly "French" meant exercising a degree of coercion not seen since the end of the nineteenth-century wars of conquest. Realizing the claim, dramatized by De Gaulle in Algiers in June 1958, that "there is in Algeria only one category of inhabitants ... des Français à part entière, with the same rights and the same duties" ${ }^{11}$ meant in practice expanding the reach of the state to reclaim both territory and population less from the FLN than from the political no-man's-land to which a century of colonialism had relegated them. This meant a massive extension of the state's effective jurisdiction and the "uplift" of welfare that inclusion within it would supposedly bring. Across the vastness of Algeria, this could only be achieved by the delegation of civil powers to the military and the execution of a massive program of social engineering that, while drawing on programs anticipated a decade earlier, was now implemented on an unprecedented scale. ${ }^{12}$ France's assertion of sovereignty over Algeria had thus never been more concretely affirmed than it was after 1958; never, in the previous 128 years of colonial occupation, had such thoroughgoing efforts been made to put it into effect across the whole space of the country and in the lives of its people. However liberalizing its ultimate intentions, this "second conquest" could only, in the circumstances, be experienced by Algerians as a new and dramatic escalation of violence - physical, economic, emotional, and symbolic-

${ }^{11}$ Speech in Algiers, June 4, 1958, in De Gaulle, Discours et messages 3:15-16.

${ }^{12}$ Much of the developmentalist agenda enacted under the Constantine Plan drew on models for rural development that had been drawn up, but left unrealized, in the local Plans d'action communale of 1946-47. I am grateful to Neil MacMaster for drawing attention to this point. 
comparable in its intensity only to that suffered by their great-grandparents a century or more earlier, when Algeria had first been conquered.

The pursuit of this war of reconquest was inscribed both in the strategic logic of France's geopolitical position after 1945 and in the liberal-humanist, republican conception of a postwar political community, transcending both geographical and cultural frontiers across France and Africa. Algeria had to be reconquered against the FLN's nationalism, which French opinion viewed as backward, atavistic, and xenophobic, and simultaneously as dangerously communist- and Nasserist-inspired. There was widespread agreement that the defense of France in Algeria was necessary, and not just to "reestablish order" and protect the persons and property of the close to one million Français d'Algérie and the many Algerians imagined to be "pro-French." Much more than this, a successful end to the war in Algeria, such as De Gaulle still hoped for at least as late as the end of 1959, was imagined as enabling a "decolonization" of the French Republic itself, including its Algerian départements, that would revive the postwar, transcontinental Republic with both its global power and its progressive, universalist vocation intact. It is this relationship between suddenly expanded republican citizenship, belatedly accelerated development, and the escalation of violence that, taken altogether, should be at the center of our understanding of the postwar crisis of France's empire and its end. ${ }^{13}$ The eventual abandonment of this vision was not simply a betrayal of the imperial Republic's history and values: it was, rather more simply, the reluctant recognition of its impossibility.

\section{The Normalization and Subversion of an "Empire of Law" (1945-1958)}

Much recent scholarship has focused on the modernizing, reforming, and developmentalist dimension of postwar European colonialism. We can now see more clearly how, in the opening years of the Cold War and from North Africa to Southeast Asia, the reinvention and reassertion of empire were frequently the orders of the day, to such a degree that when reformulated imperial ambition turned abruptly to imperial retreat, decolonization and its inevitability had sud-

${ }^{13}$ Obviously, this relationship worked out differently in different territories: there was much violence in Morocco and Tunisia, more in Madagascar, the most in Indochina and Algeria, and much less in West Africa (with the important exception of Cameroon). The difference is clearly related above all to the scale of colonial settlement as well as to geostrategic considerations, metropolitan politics, and timing. But what happened in Algeria is important both for its own sake and because of the effects, from 1956 onward, of the Algerian crisis both for politics in the metropole and for developments elsewhere in the African empire, to which Algeria had become, if anything, more central since the 1940s. 
denly to be "invented" ex post facto, turning the fact of an often unseemly, and in the French case bitterly contested, scramble out of the colonies into the fiction of a dignified transition of power. ${ }^{14}$ Older narratives of the emergence of nationstates from the obsolescence of empire have been replaced by an emphasis on imagined imperial futures: the civil, administrative, juridical, and economic reform programs that characterized the "second colonial occupation," the postwar empires" "interventionist moment," or the "late colonial state." These ambitions, and their ultimate abandonment, have largely replaced the rise of anticolonial nationalism as the central story of decolonization, a story that has important and previously unrecognized consequences for our understanding of imperialism and its legacies, in the ex-metropoles as well as in Asia and Africa. ${ }^{15}$ In the case of France and Algeria, in Todd Shepard's striking and surprising formulation, decolonization effected a "counterrevolution" that suddenly and illegally retracted from Muslim Algerians the equality of citizenship they had been promised by a putatively assimilationist policy throughout the colonial period, and which they in fact - at least de jure - enjoyed in this liberal-reformist moment at the end of empire. This, he suggests, "curtailed [within the truncated French polity] ... the protection of liberties and the possibilities of securing equality and fraternity that earlier generations of revolutionaries had struggled to expand," with "the disappearance of an imperial state that attempted until its last months, although fitfully, to make real the principles of race-blind equality and republican universality that were rooted in the history of France after the 1789 revolution." 16 Late colonialism here, in parallel with or even in place of the anticolonial insurrection, becomes a revolutionary moment. The subsequent, rapidly invented inevitability of independence - that is, of the necessarily separate political destinies of distinct, ethnically defined populations in the final sundering of what Jean Morin, as late as the end of 1960, had called the "indissoluble" ties between France and its overseas territory - becomes a counterrevolutionary exclusion from the raceblind rights of citizenship that the imperial Republic had offered. Contemporary French racism and the politics of ethnic exclusion are seen as more the result of this sudden rupture of decolonization than of the long history of empire.

Such accounts have made extremely important contributions to moving beyond the simple monochrome or Manichean accounts of colonialism offered by the older "heroic" narratives of nationalism, or by some of the less sophisticated variants of postcolonial scholarship in which, ironically, empire has appeared

\footnotetext{
${ }^{14}$ There are of course important exceptions, most notably India and Palestine, where not even the semblance of a "dignified" transition could be salvaged.

${ }^{15}$ See Cooper, Colonialism in Question, 188, for colonialism's "interventionist moment"; and Shipway, Decolonisation and Its Impact, passim, for the "late colonial state."

${ }^{16}$ Shepard, Invention of Decolonization, 2, 15.
} 
as monolithic and as coherent as the imperialists themselves sometimes believed. ${ }^{17}$ Taking the late colonial reinvention of empire and its imagined possibilities seriously, debunking the hindsight view of the inevitability of independence for nation-states in the form they eventually (but sometimes quite unpredictably) took, and breaking with both the myth of an almost omnisciently guided "handover of power" (especially in respect of De Gaulle) and the myth of a historically "natural" national destiny have been major steps. ${ }^{18}$ Such careful and critical attention to the languages and actions of serious-minded policy makers and officials who imagined themselves to be working in a progressive, even a humanitarian, cause has also been an important corrective to views of late colonialism, or indeed of "the colonial state" per se over the longer term, as constituting nothing more or less than a catalog of extreme, even exterminatory, violence. Reform and development, versions of affirmative action and legal inclusion, what Saint-Cyr and Morin thought of as the sincerely "generous and humane work" of civilization, solidarity and fraternity, all marked real attempts to put principle into practice, not merely a set of cynical self-justifications that risibly failed to mask the real interests of exploitation and repression. Ideology mattered. Colonialism and human rights, colonialism and development, however contradictory, were not simply antithetical; there was a "colonialism with a human face," however grotesque, that ought to be rediscovered. ${ }^{19}$ But while the recent emphasis on late colonialism's “developmental turn" has been important, it has arguably tended both to cut off the period after 1945 from a longer perspective, and - in the Algerian case - to misperceive the real significance of its object of analysis.

Although it became more urgent and more visible amidst rising demographic, social, and political tensions after 1945, this aspect of empire was not a sudden invention of the postwar years. French republican colonialism, as Emmanuelle Saada has observed, had from the 1880s at least built an empire founded not solely on force but also much concerned with law, and colonial administrators were perpetually preoccupied by the need to reconcile the exigencies of rule

${ }^{17}$ For the now well-rehearsed critiques of some of the (unwittingly) totalizing tendencies of some postcolonial scholarship, see Cooper, Colonialism in Question, pt. 1; Rosalind O'Hanlon, "Recovering the Subject: Subaltern Studies and Histories of Resistance in Colonial South Asia," Modern Asian Studies 22, no. 1 (1988): 189-224.

${ }^{18}$ For these points in relation to Africa, see Frederick Cooper, "Possibility and Constraint: African Independence in Historical Perspective," Journal of African Historv 49, no. 2 (2008): 167-96.

19 Alice L. Conklin, "Colonialism and Human Rights: A Contradiction in Terms? The Case of France and West Africa, 1895-1914," American Historical Review 103, no. 2 (1998): 419-42. For a critique of the imperial heritage of the discourse of human rights in another African case (Nigeria), see Bonny Ibahwoh, Imperialism and Human Rights (New York, 2008). 
in "exceptional" circumstances with the aspiration to civilized (i.e., law-bound) good government that they held themselves to embody. ${ }^{20}$ From the 1880 s until 1944, France's day-to-day governance of Asians and Africans had relied heavily on the indigénat regime that had been pieced together, decree by iniquitous decree, in Algeria and then exported to the rest of the empire. The impetus to reform colonial rule, beginning in Algeria in 1919 with discussions over the "recompense" for service rendered and lives lost from 1914 to 1918, focused just as heavily on this system's restriction and abolition. While the indigénat remained in full force in, for example, West Africa and New Caledonia until 1946, it began to be limited in Algeria after the First World War: some five hundred thousand Algerian men (43 percent of the adult male population) were removed from its jurisdiction and enfranchised as local electors by the 1919 reforms. Rural administrators lost their "disciplinary powers" in 1927 (although municipal justices of the peace retained them), and the indigénat system as a whole was finally abolished in Algeria in 1944. In 1945, then, the most offensively unrepublican aspect of colonial rule in Algeria - that which denied equality before the law to an ethnoreligiously defined category of French nationals - had already been reformed. The fuller "normalization" of the system under the rule of law, moving gradually toward equal citizenship for all along with social and economic "uplift" (as De Gaulle, ironically enough, himself promised in a first speech in Constantine in 1944), remained as the aim of a wide-ranging "renewal" agenda announced with the creation of reform commissions, the first of which was instituted in Algiers in December 1943, only a year after the seizure of North Africa from Vichy and the return of "republican legality."

As has long been recognized, the new urgency of reform in this context did indeed indicate a broader reorientation of the ideology and the priorities of the empire: the new tone set at Brazzaville in 1944, the establishment of the FIDES (Investment Fund for Social and Economic Development) program and the first ten-year plan in 1946, and the constitutional extension of citizenship and, more substantially, of labor rights transformed the spaces and the possibilities of politics across French Africa. ${ }^{21}$ Even in rural Algeria, awareness of new entitlements brought a surge of demands from assertive locals - demands that administrators found irritating and that they had neither time nor resources to meet. Access to welfare provision, especially among workers emigrating to the metropole, required official documentation; as a result, demand for birth certificates,

\footnotetext{
${ }^{20}$ Saada, "Empire of Law"; see also Lauren Benton, Law and Colonial Cultures: Legal Regimes in World History, 1400-1900 (Cambridge, 2002), and A Search for Sovereignty: Law and Geography in European Empires, 1400-1900 (Cambridge, 2010).

${ }^{21}$ Cooper, Decolonization and African Society, passim, and "Citizenship between Empire and Nation: France and French Africa, 1945-1960," paper presented to the Davis Center seminar, Princeton, NJ, September 2008.
} 
identity cards, and proof of family dependents suddenly rocketed in the countryside where interaction with the state had previously been minimal. One local administrator on the Algerian-Moroccan border, for example, described how his services were overwhelmed, forcing him to restrict opening hours. He simultaneously reported the growth of traffic in forged identity papers. ${ }^{22}$ The social and legal status of women, hitherto largely untouched by the colonial government, became a litmus test for the seriousness of the reform agenda (though the vote for Algerian women was among the measures buried in the Algiers Assembly after 1946). At the same time, some of the same themes - the extension to Algerian women of education in French and Arabic, of the vote, and of individual freedoms in marriage and family affairs - were adopted by a tentative, and as yet entirely unrepresentative, Algerian feminism. Soldiers and administrators collated data and advanced proposals for Algerian women's emancipation through French legal liberalism. A degree of similarity in preoccupations, despite its rather different tone, characterized the periodical L'Action: Revue sociale féminine, littéraire, artistique, edited by the Algerian novelist Djamila Debeche and first published in 1947. This magazine, written in French and largely by men, focused on the achievements of secularist Turkey as well as on contemporary liberal Islamic views of gender relations and on the need for education for girls. The colonial periodical France Outre-Mer (updated successor to Le monde colonial illustrée) presented Debeche, whose first novel Leilla, jeune fille d'Algérie also appeared in 1947, as "a Muslim woman of Algeria, whose culture is both Koranic and French, ... . [a] spokeswoman for her 'veiled' sisters." ${ }^{23}$

This marked expansion of the state's fields of action drew, most obviously, on the model of the interventionist state that had gained traction everywhere

\footnotetext{
${ }^{22}$ Monthly report, Administrator, Commune Mixte of Marnia, February 28, 1948. DZ/AN/IBA/ADC/196/2353.

${ }^{23}$ Debeche, "La femme musulmane d'Algérie réclame le droit d'évoluer," France Outre-Mer 314 (January 1956): 41-42; copies of L'Action for 1948 in FR/ANOM/ GGA/9X/136; 1957 proposals for the reform of women's personal status, with summary of official positions up to that date, in FR/ANOM/FM/81F/74. During the war, and particularly from 1958 onward, women (their legal status, their dress, and their bodies) became major physical and symbolic battlegrounds. For official views, see Cpt. L. P. Fauque, "Stades d'évolution de la cellule familiale musulmane d'Algérie," DélégationGénérale du Gouvernement en Algérie, Direction des personnels et des affaires administratives, Algiers, May 20, 1959 (28 pp.), a report based on 432 local studies furnished by the army's civil affairs (Section administrative spécialisée, or SAS) officers; Cpt. J. Carret, "La femme musulmane," Délégation-Générale du Gouvernement en Algérie, Service de l'action administrative et économique, Bulletin de Liaison et de Documentation 57/10 and 58/15, May 30, 1958 (60 pp.), both in FR/ANOM/GGA/9X/299. On women's status during the war, see Ryme Seferdjeli, "French 'Reforms' and Muslim Women's Emancipation during the Algerian War," Journal of North African Studies 9, no. 4 (2004): 19-61; Neil MacMaster, Buring the Veil: The Algerian War and the "Emancipation" of Muslim Women, 1954-62 (Manchester, 2009).
} 
since the global economic crisis of the 1930s before being reinforced by the prodigious expansion of the state's remit in wartime planning. It also inherited a set of preoccupations about colonial government as requiring social and economic improvements for the "valorization" (mise en valeur) of the empire that had been prevalent since the interwar period. Already in the 1920s, the concerns underpinning such programs had included geopolitical competition and imperial security: for Albert Sarraut, the principal advocate of mise en valeur in France in the early twenties, economic investment in the empire was "less ... a socially beneficial economic scheme than a security strategy" necessitated by the threat of "Communist subversion of colonial control." ${ }^{24}$ In this respect, the newly urgent geopolitical context in which post-Liberation France had to reestablish a global power posture not only against old imperial rivals but also relative to the emerging Cold War superpowers and against growing anticolonial nationalisms was a step change relative to the prewar situation in degree but not in kind.

More importantly, at the same time as it represented something less than wholly new, the postwar reform agenda also portended something rather different than it proclaimed. Reform was, indeed, everywhere in the language of the colonial state at least from 1943 onward, and it now applied to almost every domain of government and society. But what this language denoted in settlercolonial Algeria from the mid-1940s to the late 1950s was primarily an administrative process whose actual effect was the opposite of reform. In social, as opposed to political, terms, real reform did take place in some areas, especially in the prodigious expansion of education. But in the political domain, until the sudden flurry of activity after the May revolution of 1958 that toppled the Fourth Republic and brought De Gaulle to power, "reform" after 1945 referred to a systemically stalled process of consultation on all the major areas of colonial governance. Actual action to end minority rule and institute equality of citizenship for former colonial subjects was constantly deferred, entrenching an unreformable system of minority rule in which the formal rights of citizenship conferred on Algerians in 1946, and affirmed in 1958, were voided of their substance. ${ }^{25}$ After 1945, and especially from 1946, a new citizenship regime and the

${ }^{24}$ Martin Thomas, "Albert Sarraut, French Colonial Development, and the Communist Threat, 1919-1930," Journal of Modern Historv 77, no. 4 (2005): 917-55, quotes at 921, 918.

${ }^{25}$ Full citizenship for all inhabitants of Algeria was promised before the Liberation by the March 7, 1944, ordinance of the provisional government in Algiers and legislated by the inclusion of a reference to Algeria in the text of the Lamine Guèye law (law 46-940, May 7, 1946) that conferred citizenship on inhabitants of French overseas territories. Citizenship for French nationals of local civic status (i.e., those not subject to French civil law in personal status matters - notably, Algerian Muslims) was affirmed in article 82 of the constitution of the Fourth Republic (October 27, 1946) and article 75 of the constitution of the Fifth Republic (October 4, 1958). The Statute of Algeria 
assertive, contentious multiparty politics that it supported changed the formal constitutional frame and the legal space within which Algerians actively and creatively maneuvered to claim rights, advance demands, and mobilize as a political community around different visions of their political future. ${ }^{26}$ But mass politics, the overt mobilization of Algerians in public space, terrified the settlers and panicked the administration. The former began to organize to take matters into their own hands; the latter began to collude in extralegal means of containing the population that their avowed policies were supposed to be emancipating. The process of incorporating Algerians equally into the republican body politic was both stalled and subverted. The reformist and developmental agenda became correlated with a rising tide of repression.

The tone was set, emblematically enough, on and immediately after May 8, 1945, in the rural northeastern Constantinois region around the towns of Sétif and Guelma. Scuffles in the town center of Sétif between police and nationalist demonstrators who had intended to show the Algerian flag alongside those of the Allied powers on the May 8 march to the municipal war memorial led to shots being fired. In an outbreak of spontaneous communal violence, twentyone Europeans were killed and forty-eight injured; an unknown but certainly much larger number of Algerians were killed. In Guelma, a smaller, heavily policed demonstration was held outside the town, but a curfew and mass arrests in the evening were followed by the roundup and summary execution of Algerian adult males by local militia armed and organized by the former résistant subprefect, André Achiary. In Sétif, police powers were handed to the army, and troops in town were reported to be shooting Algerians on sight. As news of killings in the towns became known, a spontaneous peasant uprising spread in the hills of the surrounding countryside, mobilizing whole populations north of Sétif. It was limited to a few small bands around Guelma, but everywhere peasant grievances were directed at local targets: isolated French farms, small colonial settlements, Europeans caught on the road. The local leadership of the most

(September 20,1947) that reformed governance in the colony in fact ensured that the earlier legislation would be rendered ineffective (see below and also Shepard, Invention of Decolonization, 41-42 and n. 67). For the significance of "personal status" as a mechanism of colonial rule and a rallying point of nationalism, see Michael Brett, "Legislating for Inequality in Algeria: The Senatus-Consulte of 14th July, 1865," Bulletin of the School of Oriental and African Studies 51 (1988): 440-61; James McDougall, History and the Culture of Nationalism in Algeria (Cambridge, 2006), 88-93.

${ }^{26}$ Malika Rahal, "L’Union démocratique du manifeste algérien (1946-1956): Histoire d'un parti politique" (doctoral diss., 2 vols., INALCO, Paris, 2007), and "Prendre parti à Constantine: L'UDMA de 1946 à 1956," Insaniyat: Revue algérienne d'anthropologie sociale et culturelle 35-36 (2007): 63-77, and cf. "A Local Approach to the UDMA: LocalLevel Politics during the Decade of Political Parties (1946-1956)," Journal of North African Studies 18, no. 5 (2013): 703-24. 
militant Algerian nationalist party, the Algerian People's Party (PPA), had planned for an insurrection but could not direct it when it in fact broke out. Between May 8 and 11, the revolt, which killed 102 Europeans in all, was put down with a combined military and civilian-militia repression that probably killed eight thousand Algerians. Twenty-eight aircraft, including three B26 bombers, targeted population concentrations in the hills north of Sétif and south of Guelma; the 700-ton cruiser Duguay-Trouin bombarded the mountains along the coastline where there was "a presumption of rebel activity." ${ }^{27}$ From May 11, army units tasked with relieving isolated colonial population centers and reestablishing order systematically shelled Algerian villages with artillery fire while attempting to rein in civilian paramilitaries. A week later, massive repression forced the "submission" of the population around the Kherrata gorges along the road between Sétif and the coast. A psychologically intimidating ceremony of formal "surrender" at Les Falaises, a beach spot on the coast north of Sétif, on May 22 was followed by "mopping up" operations that lasted until the formal restoration of powers to civil authorities on June 11.

The "events" of Guelma and Sétif seemed to settlers at the time a throwback to the latent, atavistic violence of the colonized; to nationalists, they demonstrated the naked, essential violence of colonialism. They have subsequently been seen as the prelude to the war of independence, presaging the inevitable reduction of the colonial relationship to outright war. But, as Jean-Pierre Peyroulou has demonstrated, it was from this moment that the state's "developmental turn" catalyzed longer-standing communitarian tensions, heavy demographic imbalance (especially marked in this region), and the propensity of settler communities to vigilante action, producing an escalation of violence that first "subverted" republican legality and then was protected by it. It was the influx of rural Algerian peasant demonstrators into French urban, public space that terrified Europeans and tended to produce a rapid turn to violence on both sides. Nationalist party politics could not contain the more radical, grassroots peasant insurgency, and the authorities' denial of access to the street and the square turned demonstrations

${ }^{27}$ Annie Rey-Goldzeiguer, Aux origines de la guerre d'Algérie, 1940-1945: De MersEl-Kébir aux massacres du nord-constantinois (Paris, 2002), 295. On May 8 and its aftermath, see also Redouane Ained-Tabet, Le mouvement du 8 mai 1945 en Algérie (Algiers, 1985); Jean-Louis Planche, Sétif 1945: Chronique d'un massacre annoncé (Paris, 2006); Jean-Pierre Peyroulou, Guelma, 1945: Une subversion française dans l'Algérie coloniale (Paris 2009); and Martin Thomas, "Colonial Violence in Algeria and the Distorted Logic of State Retribution: The Sétif Uprising of 1945," Journal of Military History 75, no. 1 (2011): 125-58. Estimates of the death toll vary widely: the French administration's official maximal figure of 1,500 has always been dismissed as absurdly low, while the official Algerian nationalist claim of 45,000 has usually been thought much too high. The sober estimate of 8,000 was advanced initially by Charles-André Julien; the best recent discussion is in Peyroulou, Guelma, 1945, 197-202. 
into massacres. Europeans feared being "submerged" by a demographically ballooning "native" population that was no longer contained by disciplinary powers and would soon, if Paris had its way, overwhelm the fragile political preponderance of the minority "civilized" citizen community. Such fears led them to enforce the colonial order on their own terms, by extralegal, summary, and widespread killing. ${ }^{28}$ The reform agenda, in removing the low-level, everyday legal violence of the indigénat and expanding mass politics, unwittingly opened the way to large-scale extrajudicial repression.

As reform became the openly normative language of the colonial state after 1945 , its effects thus became intensely paradoxical. The disappearance of the indigénat, both as a repressive system and as the administrative-legal category of noncitizens subjected to it, meant that the routinized systems of euphemized and low-intensity violence on which the colonial system had rested since the early 1880 s broke down. At the same time, levels of disproportionate, retributive or preemptive violence, both overt and extrajudicial or "subversive," increased. The resort to force was most obviously illustrated in the events of Sétif, Guelma, and environs, both in the demonstrative application of indiscriminate and overwhelming violence by the regular military and in the deliberate mass murders carried out by settler militia that the authorities covered up in the aftermath. As Peyroulou suggests, in an isolated colonial community such as Guelma (with a population of 20,000, of whom only 4,500, including the local Jews, were "Europeans"), the military aimed at the "submission" of an insurgent peasantry while the settlers" atrocities aimed at the "extermination" of Algerian nationalism as a political and social threat. ${ }^{29}$ But beyond these spectacular events, the rise of repression is also evident in a more widely systematic use of direct coercion that arose within, and hollowed out, the growing spaces of electoral inclusion and citizenship into which the formerly subject population was being formally integrated.

The overt fraud and intimidation that marked elections in Algeria from 1948 onward have sometimes been attributed to the particularly Jacobin socialism of Governor-General Marcel-Edmond Naegelen, who saw Algerian nationalists as secessionists to be suppressed, but it has to be doubted whether any other administration would have acted any differently. Indeed, electoral fraud in Algeria survived Naegelen's resignation in March 1951 and remained systemic up to and including the vote for De Gaulle's constitutional referendum of September

${ }^{28}$ Peyroulou, Guelma, 1945. A fuller discussion is in Jean-Pierre Peyroulou, "Guelma, 8 mai 1945: Une subversion européenne dans le département de Constantine, Algérie française" (PhD diss., 2 vols., EHESS, Paris, 2007).

${ }^{29}$ Peyroulou, Guelma, 1945, 230. Settler paramilitaries may have killed up to 2,000 Algerians in and around Guelma. 
1958. In the sphere of law, similarly, as the exceptional system of "native" disciplinary justice disappeared, black holes opened up in the regular constitutional workings of the police that overcompensated for the loss. Thus, what seems to have been the beginning of a routine use of torture by the police can be discerned in the mid- to late 1940s. The dismantling of the paramilitary Organisation Spéciale of the PPA in 1950 saw the police "resort to torture on a large scale to extract confessions"; the fact that in October 1949 Naegelen had issued a circular to Algeria's prefects forbidding physical violence in criminal investigations suggests that the practice had already become widespread. Police torture was already known in Vietnam and Madagascar, and by the early 1950s it was also common in Morocco and Tunisia, where armed struggle began earlier than in Algeria. ${ }^{30}$ Among other cases in the early months of the revolution, that of Belqasim Zeddour suggests that police torture of suspects in custody was already established practice well before the escalation of the war and the large-scale adoption of such tactics by the army in the "Battle of Algiers" and elsewhere. Zeddour was a nationalist militant from Oran arrested on November 6, 1954, only five days after the FLN's first armed actions; he died under torture in Algiers, and his body was dumped inshore in a crude attempt at a cover-up. The case was exceptional at this stage only because the senior interrogator "screwed up" and Zeddour was killed. ${ }^{31}$ Such violence, of course, would reach its peak in the routinized practices of extrajudicial detention, torture, and summary execution practiced on a very large scale by both army and police against Algerians who were supposedly full French citizens, with all the rights and protections obtaining under that status, later in the war. But the violence was not itself a product of the war after 1954, whatever the exigencies of the conflict may have been taken to be; it was a structural development of the colonial state's practices of rule — or, rather, of the "real" state's own growing subversion of the "formal" state's expanding rule of law-that predated the outbreak of the insurrection by a decade.

${ }^{30}$ Raphaëlle Branche, La torture et l'armée pendant la guerre d'Algérie, 1954-1962 (Paris, 2001), 32.

${ }^{31}$ The Zeddour case was raised initially by the discovery of the body and the subsequent sentencing in absentia of a man who was already dead ("Un cadavre nu est découvert ligoté dans un sac," Journal d'Alger, November 30, 1954; "Le tribunal correctionnel d'Alger condamne Zeddour Mohamed par défaut," Echo d'Alger, January 19, 1955; interview with Muhammad Brahim Zeddour, the victim's brother, Oran, June 5, 2007). Sadek Hadjerès, a physician, nationalist militant, and subsequently secretary general of the Algerian Communist Party, affirms having himself treated Algerian suspects who had been detained in operations against the OS and tortured (interview, Malakoff, June 4, 2009). The practice of torture against suspected OS members was described by socialist journalist Claude Bourdet ("Y-at-il une gestapo algérienne?," L'Observateur, December 6, 1951); several other cases were adduced in his subsequent article, "Votre Gestapo d'Algérie," France-Observateur, January 13, 1955. 
Ironically but logically, then, it was in Algeria, the only territory of France's second colonial empire to be constitutionally incorporated as "integrally part" of France, and where inclusive citizenship therefore meant the most, that the new politics of postwar citizenship were most stymied. The reform commissions in Algiers after 1945 lost themselves in impasses and made progress on nothing. ${ }^{32}$ The Statute of Algeria, enacted in 1947 on the basis of a very conservative proposal, established an Algerian Assembly in which European and Algerian communities, in separate electoral colleges, had parity of representation and in which a two-thirds majority was required to implement major metropolitandriven reform measures, meaning that 1.3 million electors confined in the Algerian "second college" were outweighed by the 532,000 (overwhelmingly European) voters of the first. ${ }^{33}$ By 1951, the Algerian nationalist and communist parties that had mostly agreed in 1946 on pushing their agenda through legal means were united with the radical wing of the PPA in advocating a boycott of elections and denouncing the fraud and repression to which they had been systematically subjected since the municipal elections of 1945.

This blockage of the reform process up to 1951 drove the PPA's own radical, grassroots militants toward the resort to arms that some of them had insisted

${ }^{32}$ On the governance of religion, for example, a reform commission met in January 1944, but the "independence of Muslim worship" from the state was still an unresolved "problem" in 1959. (Cpt. Jacques Carret, "Le Problème de l'indépendance du culte musulman en Algérie," Algiers, Imprimerie officielle, 1959, and related papers in FR/ANOM/ GGA/9X/299.)

${ }^{33}$ To be more precise, the first college represented "citizens of common status": French citizens subject to the (secular) French civil law, mostly European settlers and their descendants but also some Algerians "naturalized" under the provisions of earlier legislation. The second college represented "citizens of local status": those formerly referred to as indigènes musulmans or indigènes juifs. (The latter term was used for a small population remaining in the Sahara after Algerian Jews living in the "civil territories" of northern Algeria gained citizenship en masse by decree in 1871. That decree was rescinded by Vichy on October 8, 1940, but reestablished by the Free French administration on October 23, 1943.) From 1865, Muslim Algerians had been considered French nationals but not citizens. After 1944, they became French citizens subject to community-specific (religious) civil law: Islamic law as codified and dispensed by the Islamic branch of the colonial civil judiciary. In administrative and especially military parlance, this second category of citizens would later be termed "Français de souche nord-africaine" (FSNA, French people of North African origin) in contrast to "Français de souche européenne" (FSE, French people of European origin) - terms that became ubiquitous during the war of independence. See James McDougall, A History of Algeria (Cambridge, 2017), 122-27, 147-60, 183-85, 217-18. On the 1947 statute, the Algerian Assembly, the second college, and their antecedents, see Claude Collot, Les institutions de l'Algérie durant la période coloniale (1830-1962) (Paris, 1987); and Jean-Claude Vatin, L'Algérie politique: Histoire et société, 2nd ed. (Paris, 1983). 
was necessary ever since 1945 . The party's paramilitary wing, the Special Organization (OS), created in 1947 at the same time as its first deputies were taking their seats in the National Assembly in Paris, was dismantled by the police in 1950, but its underground militants intent on armed struggle henceforth set the tone for the wider movement, which by 1956 would have little trouble in rolling up the surviving advocates of legal opposition into the FLN's mass movement for armed struggle. The "preemptive" violence of repression in 1945 and the attempt to contain Algerian political demands by fraud, intimidation, and arrests - prompted by the view, long held by the colonial state and the settler community alike, that calls for Algerian emancipation, however "loyally" oppositional, were threats to French sovereignty - thus produced a real threat, which in turn was countered with increasingly violent repression. Repression, in turn, cut the ground from under legal opposition and fed support for the movement that, in 1954, former militants of the OS would launch in the new name of the FLN.

The reaffirmed project of the French colonial empire after 1945 spoke a liberal language of reform, inflected and magnified by the changed international circumstances of economic and military balance and by the new emphasis on governance as development and welfarism in the postwar world. It was also rooted in the much longer history of a reforming, civilizing self-image whose emancipatory promise of the rule of law, both to itself and to its colonial subjects, had always been trapped in the exigencies of rule "in the meantime" by violence, physical or euphemized, meaning that life under the everyday colonial state had been life in an institutionalized state of exception. In this permanent, never normalized, but certainly routinized state, the principled insistence on the potential access of colonial subjects to universal rights of participation and self-direction and the anticipated development of their standards of livingin short, their "assimilation" to the benefits of belonging within the French body politic - could only ever reiterate the constant deferral of the realization of these principles. The vaunting of such principles merely perpetuated a self-mystifying fantasy, a story the rulers of France's empire told each other (and everyone else) to explain themselves to themselves, a fantasy that was both necessary and ideologically effective in the maintenance of colonial rule through unaccountably exceptional measures "in the interim."

But as this "interim" state of affairs at last made way formally for the rule of law after 1945, as mass politics gained ground, and as the formerly subject population increasingly demanded access to constitutional and physical public space, so constitutional rule was undermined from within, even as it expanded-as reformers believed it must - into those spaces hitherto occupied by the longstanding, supposedly transitory, measures of "exceptional" colonial jurisdiction. While on one level the result of a deliberate, voluntarist choice - that of a radical 
minority within an embattled and factionalized nationalist movement - the descent into war, between 1954 and 1956, was at the same time the inexorable outcome of this process. It would be the escalation of the war, an equally deliberate but equally unavoidable result of institutional logic and predominant beliefs, first in 1956 and again, especially, after De Gaulle's return to power in May 1958, that would both unblock the reform agenda and pursue the counterinsurgency with unprecedented vigor. Reform now, after a decade's hiatus, meant something positive again: now it meant reconquest.

\section{The Ideologies and Practices of a Colonial Reconquest (1958-1962)}

The ceremonies at El Ouennane look, in hindsight, like the ludicrous celebrations of a lost cause. But what in retrospect seem to have been the very last ditches dug in the long struggle to make Algeria French came at a moment when, for many French planners, it seemed as though the war was in fact won. And although the political resolution likely to emerge from the conflict was not yet clear, it was to them clearly French agency and initiative, French policy and practices of governance, that would determine the future shape of Algeria and its relationship to metropolitan France. Those charged with the implementation of France's counterinsurgency war saw themselves as engaged in a forward-looking reinvention of France's global influence and responsibility, recasting the shape of the French nation-state, its regime of citizenship, and its geopolitical significance. This implied a sudden, astonishingly belated but massive development drive, finally putting into action the social and economic mise en valeur often touted, but little implemented, since the $1920 \mathrm{~s}$, along with an accelerated process of political and social reform that had been much discussed, but, as we have seen, little acted upon, since 1944.

Like colonialism itself over the longer term, however, the French civil, economic, and juridical reconquest of Algeria was not a single-minded and coherent project, but a bundle of sometimes conflicting imperatives spanning a range of positions. At the maximalist end of this range, the simultaneous pursuit of developmental investment and political reform alongside, and as a goal of, the prosecution of the military counterinsurgency campaign was expected to achieve the reconquest of an Algeria to be rebuilt and reformed under French tutelage once it had been effectively "pacified." Many, both in the French military and among Algeria's European population, thought this stage had in fact been reached after the Challe offensives of February-August 1959 had systematically combed the rural landscape from west to east, mostly reducing the ALN in the maquis to small, fugitive bands in the mountains, deprived of cover and support and harried by airpower, heliported troop deployments and commandos de chasse. In early September 1959, De Gaulle apparently told his finance min- 
ister, Antoine Pinay: "It's finished. The war is over . . . they will sue for peace on their knees." ${ }^{34}$

A good deal of French military documentation produced after May 1958, both in internal theorizing and in overt publicity, stressed this dimension of the conflict: the "rebellion" had been merely a destructive rampage by fanatics led astray under the influence of communism, and the counterinsurgency war was the necessary prelude to the reconstruction of Algeria, whose future within the free world depended upon the will of France to keep Algeria French. Leaflets distributed to conscripts returning home on leave in the second half of 1958 explained:

You have been called to serve in Algeria; why? Because the world revolution . . . has swept down brutally on the French province of Algeria; and because the fellagas, ${ }^{35}$ duped by the lies of the FLN and its chiefs, bought by Moscow, have shed on the French soil of Algeria the blood of their brothers, their wives, their families, and their children. The rebel movement in Algeria is a phase of the struggle undertaken against the West by the ambitious leaders of pan-Arabism in the service of Soviet communism. This dictatorial, racial, and therefore xenophobic movement has found support by exploiting a certain religious fanaticism. Its "struggle for liberty" is in fact a systematic effort to impose a regime of terror upon the people. ... Through combat, you have silenced the guns of the fellagas; through humanity, you have returned life and liberty to these brothers who had gone astray; through pacification, you have shown kindness to the Algerian, you have educated and cared for him; through education, you have convinced him of the greatness of France. In May 1958, you achieved victory: French Algeria, your victory. . . . You are the soldier of a victory that has not always been understood: you must make your victory understood. ${ }^{36}$

The text was illustrated with photographs demonstrating destructive FLN attacks on property, schools, and farm equipment, juxtaposed with images of captured weaponry, schoolchildren at desks, Algerian and French men sharing cigarettes, women and children by a fountain at a new high-rise housing project, and the towering rig of an oil installation.

These tracts were produced by the cinquième bureau, the psychological operations office of the staff of the tenth military region, the French army's orga-

${ }^{34}$ J.-R. Tournoux, La tragédie du Général (Paris, 1967), 345. For a reevaluation of the development of De Gaulle's Algeria policy, see Julian Jackson, "De Gaulle et l'Algérie: Grand dessein ou adaptation empirique?," paper presented to the colloquium "Pour une histoire critique et citoyenne: Le cas de l'histoire franco-algérienne," École normale supérieure, Lyon, June 21, 2006, available at http://ens-web3.ens-lsh.fr/colloques/france -algerie/communication.php3?id_article $=240$ (accessed November 20, 2008).

35 "Bandits," a vernacular Arabic term taken up as French army slang for the Algerian guerillas.

36 "Jeune français métropolitain ...," printed pamphlet (4 pp.) FR/CADN/Alg/Amb (DG) $/ 52 / 1$. 
nizational designation for Algeria. ${ }^{37}$ Established in March 1955, the cinquième bureau directed much of its work at the army itself to "explain" the importance of the armed forces' mission in Algeria, a mission considered to be generally misunderstood at home in France and by the conscripts themselves. ${ }^{38}$ In much of the thinking along these lines a clearly Cold War geopolitical logic was combined with the restatement of an older conception of the colonial "civilizing mission" and with a renewed affirmation of the intimacy of the connection between France and Algeria. This was an intimacy formed from the community of citizenship that indigenous North African and European-settler populations were imagined to share with the metropolitan "Français de France" and from the community of destiny that all shared in the imagined global struggle of Western civilization against communist subversion.

Thus, in April 1959, Colonel Lalande, the adjutant to the chief of the general staff for psychological operations in Algiers, wrote in his instructions for indoctrination sessions aimed at newly arrived soldiers and NCOs that the French were fighting not merely against fellagas but also against "a war conducted . . . by totalitarian means, aiming at the conquest of the whole world, by Bolshevism," a war whose "objective is the enslavement of man within the collectivity in the service of material evolution." "Here [in Algeria]," he went on, "we are defending neither capitalism nor colonialism, nor Algeria. ... We are defending the French people, all of them; we are defending France, our motherland, which is made not only of men and of goods but of the very values of our civilization, founded on the dignity and the development of Mankind; here, we are fighting . . . in the vanguard of the free world." Such a struggle against the material dehumanization threatened by communism implied a values-driven, humanitarian

37 The cinquième bureau in Algeria was dissolved in the aftermath of "barricades week," January 24-29, 1960, when the right-wing Front National Français (a forerunner of the OAS) attempted to spark an insurrection to swing the army and authorities away from pursuing Algerian self-determination - an effort in which some of the section's officers, as politicized partisans of Algérie française, were implicated. Its fundamental ideas, however, enjoyed a long continuity in Algeria and elsewhere. The literature on the French army's theorists of guerre révolutionnaire is abundant: for a summary, see Denis Leroux, "La 'doctrine de la guerre révolutionnaire': Théories et pratiques," in Histoire de l'Algérie à la période coloniale, ed. Abderrahmane Bouchène et al. (Paris, 2012), 526-32.

${ }^{38}$ On the course and impact of the war in France, see Raphaëlle Branche and Sylvie Thénault, eds., La France en guerre, 1954-1962: Expériences métropolitaines de la guerre d'indépendance algérienne (Paris, 2008); and the essays on "La métropole, un espace de la guerre," in Bouchène et al., Histoire de l'Algérie à la période coloniale, 576-605; on the wider context, see also Neil MacMaster, Colonial Migrants and Racism: Algerians in France, 1900-1962 (New York, 1997); and on the Parisian repression of October 1961, see Jim House and Neil MacMaster, Paris 1961: Algerians, State Terror, and Memory (Oxford, 2006). 
war: "To win, we must above all struggle within ourselves and around us. . . We must struggle against fear ... and hatred ... by knowing the [indigenous] population, informing them objectively and educating them; the aim . . . is to bring the population alongside us to participate in the construction of Algeria. ... We have the right to destroy here only because we have the duty to build." ${ }^{39}$ This theme was repeated in the official line announced throughout the army in Algeria from 1958 onward. Lalande provided an example of the lectures given to soldiers under the title "Why we fight: how we fight":

We destroy only in order to construct. To destroy means, not physically to eliminate, but to prevent from doing harm.... Construction means replacing the rebel ideology with the values of our civilization; to give the local population a solid structure permitting them to resist rebel pressure; to build in every way. ... We must free the inhabitants [of Algeria] from fear. . . The people we defend here are French people under threat, French people of European origin and especially French people of North African origin. ... The things we defend here are our country, our village, family, father, mother, sister, friend, and today and for tomorrow, our children, here and in the metropole. What we defend here is ... the motherland: the physical motherland, our lands, our goods, our people. And the spiritual motherland: our ideas, our civilization, our writers, our thinkers. ${ }^{40}$

Schemes for such lectures were distributed in their thousands in the summer of $1958 .^{41}$ The themes evoked continued to filter through into French propaganda directed at Algerians almost to the end of the war. Bilingual tracts distributed by the army after an FLN attack on an irrigation project at al-Ajraf, near Orléansville in the Cheliff valley, in April 1961, for example, told the local peasants that "these criminals [the FLN] were afraid to attack the forces of order, and in their anger preferred to destroy works that brought welfare to the whole community of poor inhabitants. The revolutionaries have committed this reckless crime, which has caused destruction only to you. It is essential that you should know that only France works for your welfare." 42

At the same time, the same language was enthusiastically adopted by the settler lobby that was becoming increasingly alarmed by the "drift" of De Gaulle's

\footnotetext{
${ }^{39}$ Note de service, Col. Lalande, General Staff, 5ème bureau, Algiers, April 13, 1959, $\mathrm{FR} / \mathrm{CADN} / \mathrm{Alg} / \mathrm{Amb}(\mathrm{DG}) / 52 / 1$.

40 "Exemple de causerie destinée aux forces armées" (16 pp.), attached to Note de service, Lalande, Algiers, April 13, 1959, FR/CADN/Alg/Amb(DG)/52/1.

41 "Schéma de causerie (à l'intention des appelés métropolitains servant en Algérie)," General Staff, 5ème bureau section OPS, Algiers, July 1, 1958 (4 pp.), FR/CADN/Alg $/ \mathrm{Amb}(\mathrm{DG}) / 52 / 1$. Five thousand copies of this instruction were printed. Stressing the wider geopolitical dimension of the war, officers giving such talks were instructed to use a wall map of the world.

${ }^{42}$ Copies of tracts distributed by the army (in French and Algerian Arabic), attached to note, Prefect, Orléansville, to Delegate-General, Algiers, April 27, 1961, FR/CADN $/ \mathrm{Alg} / \mathrm{Amb}(\mathrm{DG}) / 39 / 9$.
} 
Algeria policy and that by 1960 was itself being monitored by the administration as a subversive threat. A "Manifesto of French Algerians" circulating in Ain-Temouchent, in the region of Oran, in December 1960 declared that "France is leading, in Algeria, the fight of the free world against Bolshevik subversion. ... [We are] conscious of the urgent need to integrate underdeveloped populations into the modern society of the twentieth century. . . Only France is today capable of promoting the evolution of underdeveloped populations within the framework of the respect of human rights." 43 Public letters of opposition to the Evian negotiations in March 1961 affirmed that "Algeria within the French Republic is simultaneously the keystone and the construction-site of a new edifice, both European and African, where each will have his place while retaining his particularity and which, alone, will be capable of pursuing the struggle that the threat of communism imposes upon us." 44 OAS pirate radio broadcasts in October 1961 adopted in turn the role of countersubversion from the incumbent French authorities, appealing to America and its allies for recognition that "the struggle of the OAS is part of the defense of the free world against communism." $" 45$

At the minimalist (and, from 1961, perhaps more realistic) end of the spectrum, the aim of the twin military and civil struggle in Algeria was to preserve the "close association" between France and Algeria, to maintain the "union" of metropole and overseas territory if possible, but in any event to keep an internally autonomous, self-governing, or even independent Algeria within the French orbit and to prevent it from slipping entirely into the Soviet bloc. As already indicated, this geopolitical preoccupation was perhaps the overriding concern, both among military planners and among the developmental technocrats who were increasingly responsible, from 1959 onward, for what were seen as the more fun-

43 "Manifeste des Français Algériens," quoted in note, Délégation générale (Affaires politiques), Oran, December 3, 1960, FR/CADN/Alg/Amb(DG)/39/9. The "manifesto" supported a renovated French Algeria with equal citizenship for all within a new, regionalist national organization of France, thus combining the universalist citizenship usually associated with republicanism with an old idea of the conservative, rural French right, which from Mistral to Pétain had idealized the nation as rooted in regional terroirs.

${ }^{44}$ Marc Lauriol and Philippe Marçais, "Lettre Paris-Alger no. 17," March 22, 1961, FR/CADN/Alg/Amb(DG)/39/9. Lauriol and Marçais were the Paris-based sponsors of the group "Regroupement national pour l'unité de la République," which in early 1961 was attempting to organize opinion against the mooted (but at this point, ultimately abortive) Evian meetings. The OAS would assassinate the mayor of Evian on March 31; talks began there in May.

${ }^{45}$ Summary of OAS radio broadcast, October 12, 1961, in report on OAS broadcasts, (7 pp., 14 pp., appendixes), Delegate-General in Algeria, Rocher Noir [Boumerdès], to Minister for Algerian Affairs, Paris, November 10, 1961, no. 3447/CAB/AP/INF, p. 4, $\mathrm{FR} / \mathrm{CADN} / \mathrm{Alg} / \mathrm{Amb}(\mathrm{DG}) / 39 / 7$. 
damental tasks of the social and economic management of Algerian affairs in a political and military context that was recognized as being transitional. Indeed, some of the technocrats "parachuted" from Paris into the new administrative city at Rocher Noir (Boumerdès) east of Algiers, built in late 1961 to house the expanded French bureaucracy at a safe distance from the city's restive Europeans, may have begun to see themselves as actively preparing an inevitable (political) decolonization rather than effecting a durable reassertion of sovereignty in the aftermath of the "pacification" that they, too, thought almost complete. ${ }^{46}$ The continuity of development projects was thus envisaged beyond the end of the war, whatever its outcome - and, of course, in the event, the independent Algerian state was to inherit almost all of its flagship programs of industrialization, housing, and infrastructural development from the "Constantine Plan" that had been launched after De Gaulle's speech in the city of Constantine, in eastern Algeria, on October 3, $1958 .^{47}$

The Constantine Plan was projected to run from 1959 to 1963, and its ambition was immense: in February 1961, the official bulletin of the CEDA, the Algerian Development Fund that had been set up to finance and implement the plan, explained that when the rate of demographic growth in Algeria was accounted for, the goal of a 6 percent increase in annual per capita revenue implied a real per capita growth rate of 8 percent per annum. Funds for the project had been increased, in 1961, from three to four billion francs. But beyond this, the social as well as the economic task was more colossal still:

The aim is to remedy the fundamental imbalances of Algeria: the social imbalance that allows three and a half million citizens enjoying a European or Mediterranean standard of living to live alongside six and a half million citizens whose standard of living is barely higher than that of the other underdeveloped countries of Africa. The aim is to ensure that modern life reaches not only Algeria's coastal cities and towns, but also the whole countryside of plains and mountains. . . . Algeria must conquer, by its labor and for all its inhabitants, its full participation in the civilization of the twentieth century. France must

\footnotetext{
${ }^{46}$ The building of a new administrative center out of reach of Algiers' assertive popular politics was decided in March 1961, a month before the attempted putsch by Generals Jouhaud, Zeller, Challe, and Salan, and doubtless in light of the events of May 1958. The development of Rocher Noir as a major infrastructural project in itself was covered in the Bulletin de la caisse d'équipement pour le développement de l'Algérie (hereafter Bulletin de la CEDA), no. 9, October 1961.

${ }^{47}$ The short speech emphasized the importance of Algeria's "close solidarity with the French metropole" and the need to develop the country's resources and the living standards of the whole population, aims "which France has the capacity to achieve here, and that only France has the means to realise"; De Gaulle, Discours et messages, 4:4851. Television newsreel footage of the speech can be seen at http://www.ina.fr/histoire -et-conflits/decolonisation/video/CAF88024344/le-general-de-gaulle-a-constantine -discours.fr.html (accessed October 11, 2012).
} 
assist in this development, which is the indispensable condition for the peaceful coexistence of Algerians of different communities, as it is for safeguarding the close union between Algeria and France. ${ }^{48}$

Such a conception of the socioeconomic development necessary to save the "union between Algeria and France" therefore amounted to a decolonization of the Republic, beginning with the outdated state of Algerian property relations. In April 1961, the bulletin railed against the impossible situation bequeathed to rational planners by a century of colonial agriculture:

The figures for property in Algeria take us back to "l'Algérie de Papa." French settlers have a net agricultural income half as high again as that of Muslim farmers. This would be acceptable if the two communities were equally represented [in the landowning population], but the former are almost thirty times fewer than the latter $(22,000$ against 630,000 ). They [the Europeans] evidently possess very large properties: 90 percent of European-owned land is in the hands of 6,835 persons. "Three quarters of the area irrigated by large-scale reservoirs," as the authors of that very remarkable official publication, the Tableaux de l'économie algérienne, cruelly observe, "are farmed by non-Muslims. ${ }^{\prime 49}$

Such observations would hardly have been out of place in the arguments of liberal Europeans opposing the war, and indeed had been made for decades before the war by Algerian nationalist spokesmen.

And yet, across this spectrum of positions in which, at one end, psy-ops officers articulated their campaign for "hearts and minds" while collecting information under torture, while, at the other, agronomists and economists envisaged the newly fraternal Algeria that only France had the resources to build, a crucial continuity of preoccupations and aims prevailed. Ideas of "codevelopment" and progress through the construction of "Eurafrique" (a term that experienced a major revival in policy making and publicity in the late 1940s and

${ }^{48}$ Bulletin de la CEDA, no. 3 (February 1961): 1-2. The Bulletin was the publicrelations magazine of the Constantine Plan administration, based in Paris; it first appeared in December 1960 and was published monthly. Its remit, as expressed on page one of the first issue, was "to describe the forward march of Algeria; to demonstrate the actions being taken by the men and women of this land to draw themselves up together to the level of the twentieth century; to explain the joint efforts of metropolitan France and Algeria." Suspended after the March 1962 issue (no. 14), which coincided with the ceasefire, it reappeared at the very moment of independence with an issue (no. 15) for June-July 1962, in a new, briefer format carrying more theoretical essays on planning and perspectives. The last edition would be no. 17 (March 1963).

${ }^{49}$ Jean Ferran, "Le drame de l'agriculture algérienne," Bulletin de la CEDA, no. 5 (April 1961): 5-20. In fact, the inequality of income distribution was much more marked than this suggests. 
early $1950 \mathrm{~s}^{50}$ ) as an economic and political bloc for the preservation of France's geopolitical position - and, from 1956, with the support of Saharan oil and gas, France's economic position and energy security-were common currency. And whatever the eventual political outcome, in the immediate term the aims and means of the forcible reassertion of sovereignty by the military and the human development and infrastructural investment of the technocrats were the same: the expansion of the capacity of both civil and military powers to encompass both the space and the people of Algeria, for the reconquest of both territory and population, through the extension of the state and the "integration" of Algerian society into the French body politic. This, it was belatedly realized, colonial rule had never yet in fact achieved, and the Fifth Republic's legislation for equal citizenship had still left it unfulfilled.

Only by such means could the FLN's anticolonial revolution be defeated, but its defeat was only the means to a greater end. Jean Ferran, the writer just quoted on the iniquities of colonial property relations, went on in the same article to give a particularly clear statement of the project he shared with the army's experts in psychological warfare. Critiquing the Constantine plan's emphasis on industrialization, Ferran identified the crucial problem as lying in the countryside and in access to land, in the disparity between the landless or land-poor peasantry and the large landowners. Arguing that projected land reform (which was "too slow and too little") should go much further, he wrote: "Every revolution that breaks out today in an under-developed country resolves itself by agrarian reform. And the Constantine Plan is revolutionary when it announces that its aim is to drag the Muslim masses out of their medieval obscurity. . . . It is high time that this rural resurrection should . . . become the business of everyone. Such must be the second conquest of Algeria." 51

Bringing Algeria fully into France and into "civilization," then, meant more than anything a reengineering of rural society and the rural habitat. In 1954, as administrators and the military suddenly observed, much of rural Algeria knew the colonial state only through the often heavy-handed but thinly distributed coercion of its local auxiliaries: the qa'ids and rural constables who were gener-

${ }^{50}$ This idea had longer roots, back into the nineteenth century, and the terms Eurafrika, Eurafrica, and Eurafrique were coined by pan-European colonial idealists in the 1920s and early 1930s. In the interwar years, Eurafrique was a utopian internationalist theme, before becoming associated in the early 1940s with visions of European world power now united by the Nazi "New Order." It was revived in a quite different, specifically French imperial, context after 1945. Charles-Robert Ageron, "L'idée d'Eurafrique et le débat colonial franco-allemand de l'entre-deux-guerres," Revue d'histoire moderne et contemporaine 22, no. 3 (1975): 446-75; Papa Dramé and Samir Saul, "Le projet d'Eurafrique en France (1946-60): Quête de puissance ou atavisme colonial?," Guerres mondiales et conflits contemporains 216 (2004): 95-114.

${ }^{51}$ Ferran "Le drame," 12-13, 20 (emphasis added). 
ally the first targets of FLN attacks. The extension of more effective control into this historically "underadministered" territory began in February 1955, under the energetic governor-generalship of Jacques Soustelle (whose own humanitarian universalism had made him an interwar antifascist and wartime resister before it made him an advocate of Algérie française and of the OAS). It was expanded from 1956, with the escalation of the war on both sides, and especially after the launch of the Constantine Plan in October 1958. With the abolition of the communes mixtes (rural districts that had never been granted municipal selfgovernment), the integration of the rural population under more effective administration and their political representation within the French state could at last be achieved. ${ }^{52}$

The ambitious scale of this program, in the face of economic and social conditions that demanded total transformation, can hardly be overstated. It implied the reinvention of the rural habitat and thereby of rural society, in particular through land reform and rural resettlement. It also aimed to reinvigorate the agricultural economy in a context where the peasant milieu not only had borne the brunt of a total revolutionary and counterinsurrectionary war but also had suffered before 1954 from generations of progressive impoverishment and migration to the cities and their shantytowns that had been growing since the 1930s. The extent of actual implementation betrays the limited means deployed in the realization of the projected land reform. Of 250,000 hectares of land earmarked for redistribution under the Constantine Plan, only 28,000 hectares had been allocated by June 1960, and the 460 plots ready for occupation had no one to take them. As François Burgat and Michel Nancy observed in their study of the agrarian reform program as the background to the later "socialist villages" plan of the early 1970s, "the problem was essentially political—-the peasantry simply refused." 53

In contrast, more directly coercive measures of rural societal reengineering had a massive, profound, and lasting impact, and it was here, in the regroupements - the forcible population resettlements carried out by the army across wide swathes of the countryside - in the fantasies spun out of them and the reality experienced within them, that the developmental reconquest found its fullest and starkest expression. ${ }^{54}$ By 1961, according to the courageously early

${ }^{52}$ The abolition of the communes mixtes and their replacement with regular, selfgoverning municipalities had been a demand of Algerian reformers since the 1930s; it was anticipated by the 1947 Statute of Algeria but not applied until 1956, by the end of which year all elected municipal councils were in any case dissolved.

${ }^{53}$ François Burgat and Michel Nancy, Les villages socialistes de la révolution agraire algérienne, 1972-1982 (Paris, 1984), 34.

${ }^{54}$ I use the term "forcible resettlement" to convey the involuntary nature of the population movements concerned, although in some cases, it must be pointed out, especially early on in the war, the initiative for regroupement came from civilian populations them- 
work of Michel Cornaton, regroupement operations had resettled at least 2,350,000 people, or a quarter of the total Algerian population. If people "rehoused" in towns are included, the total rises to 3,525,000. Other subsequent estimates are slightly lower, but a consensus can be said to suggest that some three million people in all, or fully half of the Algerian rural population, were affected. ${ }^{55}$ The scale of forced resettlement was clear to the military authorities responsible for it, as was its potential valorization in the language of reform. A November 1959 military report for western Algeria, showing the locations of 402 centers housing 348,000 people, stated that while "necessitated initially by the imperatives of security, regroupements today represent one of the most effective means for the achievement of human development [la promotion de l'homme] in Algeria"; the completion of this "profoundly humane work" was to be "the true cornerstone of pacification." 56

From late 1959, French planners began the attempted reinvention of what had previously been the strictly ad hoc, operationally driven practice of regroupe-

selves. Where local notables or family leaders were hostile to FLN demands or exactions, or where the local dynamics of the war divided rural areas into "pro-French" and "pro-FLN" camps, whole populations sometimes sought protection at the nearest army post. (The regroupement at Bou Maïza, considered below, was said to have begun in this way in April 1959; for official reports this became the preferred explanation of the origins of the program - see Gen. Parlange, "Contribution de l'Inspection générale des regroupements au rapport d'information générale," Algiers, August 13, 1960 [16 pp., plus appendixes, photographs], p. 1, FR/CADN/Alg/Amb(DG)/51/6) It ought not to be thought, however, that such movements were spontaneously "voluntary," nor that they were necessarily motivated by active "loyalty" to the French. More practical considerations of security and more local considerations of politics almost certainly meant more in most cases, and for most of the individuals concerned, such moves were probably still "forced."

${ }_{55}$ Michel Cornaton, Les regroupements de la décolonisation en Algérie (Paris, 1967), and "Les camps de regroupement de la guerre d'Algérie," paper presented to the colloquium "Pour une histoire critique et citoyenne: Le cas de l'histoire francoalgérienne," École normale supérieure, Lyon, June 21, 2006 (text available at http:// ens-web3.ens-lsh.fr/colloques/france-algerie/communication.php3?id_article $=259$, accessed October 11, 2012). For other estimates, Pierre Bourdieu and Ābdelmalek Sayad, Le déracinement: La crise de l'agriculture traditionnelle en Algérie (Paris, 1964), 13; Burgat and Nancy, Villages socialistes, 36. On the impact and later legacy of rural resettlement, see also Keith Sutton's articles, "Population Resettlement: Traumatic Upheavals and the Algerian Experience," Journal of Modern African Studies 15, no. 2 (1977): 279-300, "Algeria's Socialist Villages: A Reassessment," Journal of Modern African Studies 22, no. 2 (1984): 223-48, and "Army Administration Tensions over Algeria's Centres de Regroupement, 1954-62," British Journal of Middle Eastern Studies 26, no. 2 (1999): 243-70.

56 "Regroupements de population en Oranie," report by Gen. Gambiez, officer commanding army corps Oran, to Delegate-General, Algiers, November 5, 1959, with additional note, November 14, 1959 (11 pp. plus map), FR/CADN/Alg/Amb(DG)/52/3. 
ment as a planned urbanization and "modernization" effort (what Samuel P. Huntington would later, in reference to the similar "strategic hamlets" program in Vietnam, call "forced-draft urbanization and modernization" ${ }^{\text {") }}$ ). This was the program of " 1,000 new villages" celebrated by the boosters of the Constantine Plan as "a gigantic work of construction" and routinely showcased, in the closing years of the war, to visiting journalists and dignitaries as demonstrating the human face of pacification. "'You see,' says the young subprefect, proud as can be to show off one of 'his' new villages to a group of visitors, 'misery is bearable only when it is hidden and scattered [in the countryside]. You can't resettle misery. To give these people... only what they had when they were dispersed in their hamlets on the mountain, would be impossible. It would have been a shocking concentration of poverty. It was immediately necessary to do much more." Doing "much more" for these populations, removed from their impoverished homes and lands and set to work building new, orderly, and permanent population centers under the guard of the army and its auxiliaries, posed immense challenges but also produced impressive figures: by the end of 1960, 1,200 "new villages" could be said to exist, housing 232,000 families or one million people. Eighty-four thousand solid-construction houses had been built; 2,664 school classes had opened for 125,000 children; 564 youth, sports, and professional development centers had been created; 835 nursing stations giving access to aid dispensed by 1,208 doctors and medical auxiliaries had been set up. The whole enterprise, for 1960 alone, had cost eighteen billion old francs; the establishment of each village had mobilized the expertise of "a real technical commando unit" of administrators, army civil affairs officers, surveyors, agronomists, civil engineers, advisers on forestry, agriculture, water management, and public health. The authorities also insisted that, wherever possible, representatives of the resettled population should also be included in planning, "so that the inhabitants can make their opinion known, and develop the habit of participation in the preparation of their future." Finally realizing the long-touted goal of "communal reform," resettlement villages were given appointed municipal councilors who "have now learned to take on most of the responsibilities that their role normally entails." 58

It was within this context that the civic sponsorship of resettlement "villages" by French municipalities was begun. At the time of its completion, the "adop-

${ }^{57}$ Samuel P. Huntington, "The Bases of Accommodation," Foreign Affairs 46, no. 4 (1968): 642-56, 652.

58 Jacques Boetsch, "Les mille villages," Bulletin de la CEDA, no. 6 (1961): 17-27, quotes at 18, 19-20, 23-24, 21. On the humanitarian aspects of the counterinsurgency campaign (especially medical assistance) and the wider context of the war, see Jennifer Johnson, The Battle for Algeria: Sovereignty, Health Care, and Humanitarianism (Philadelphia, 2015); on the SAS, see Gregor Matthias, Les sections administratives spécialisées en Algérie: Entre idéal et réalité, 1955-1962 (Paris, 1998). 
tion" by the département of the Ain of the regroupment camp at El Ouennane was a "one-of-a-kind scheme in Algeria," and certainly in retrospect it seems an especially remarkable manifestation of the planners' belief in their own propaganda. But the idea was taken up elsewhere too, and two examples from the far side of the country, the camps of El Meridj and Bou Maïza in eastern Algeria, give a fuller sense of the situation as it was on the ground, and of the meanings that developmental imperialism sought to create in it.

El Meridj was a resettlement situated on the inland high plateaux at the far eastern edge of Algeria, only 2.5 kilometers from the Tunisian frontier across which (before the French army completed an electrified and barbed-wire barrier in September 1957) tens of thousands of Algerian refugees had settled in camps administered by the FLN and where the nationalists' armed forces were increasingly based. According to the local military commander, Denis Bogros, El Meridj had "several times been subjected to rebel attacks from Tunisian territory," but, thanks to the protection of the army and its own self-defense militia, the concentration of the population in a new "municipality" under military supervision had "enabled the healthy elements of the population to exercise their political choice" (a permis le choix politique aux éléments sains de la population). As a "base for pacification," the settlement had "allowed serious study of all the political, economic, and social problems faced by the underdeveloped population [la population sous-évoluée] of the high plateaux." El Meridj had, then, become the center of a "peace offensive" throughout the district, resulting in "social development . . . the creation . . . of intellectual, fraternal, and economic life, in a new human grouping [the agglomerated commune] previously unknown to this [semi-nomadic] population." 59

This view of things was illustrated in the photographs accompanying Bogros's report, with handwritten captions illustrating the work of the resettlement administration: a pair of famished mules dragging an elementary wooden plough across the semiarid soil sum up the underdevelopment that has "always" existed here; the helplessness of the population is seen in the concentrated face of a young boy whose father had been killed "defending the [center] against the outlaws"; underdevelopment and insecurity had been overcome by concentrating the population in a "township" (commune), where the provision of security, thanks to the proximity of the army and the electrified border fence, and the establishment of "liberty and democracy" allowed "men of goodwill to devote themselves to the

${ }^{59}$ Report by Cpt. Bogros, officer commanding SAS, El Meridj, October 7, 1959 (3 pp.), $\mathrm{FR} / \mathrm{CADN} / \mathrm{Alg} / \mathrm{Amb}(\mathrm{DG}) / 51 / 3$. A less formal but fuller account is in Bogros's confidential CHEAM (Centre des hautes études d'administration musulmane) dissertation, "La révolution communale en Algérie ou le décret 56-642 du 28 juin 1956: Contre offensive révolutionnaire (1958)," November 27, 1958 (12 pp), FR/CAC/20000046/108/2979. 
peaceful struggle for social development." ${ }^{60}$ Here, Bogros wrote, "it is France that is making the real revolution." 61

A similar story of grand designs conjured out of the most unpromising circumstances is evident in the documentation produced on the Bou Maïza camp, a resettlement in the district of the port city of Bône (Annaba) on the northeastern Algerian coast. In June 1959, the camp, composed of huts and canvas army tents behind barbed wire fences (fig. 1), housed 2,100 people. A dispensary was planned, and though this had not yet been built for lack of funds, free medical assistance was delivered by the army once a week - which, according to the local commanding officer, was "clearly insufficient." But the establishment of "security" had permitted the "protected" population to maintain their livelihood, and social development was being relentlessly pursued, especially through schooling. One-third of the population concentrated at Bou Maïza were children under the age of eighteen, and use of a school four kilometers away had been arranged for them. ${ }^{62}$ Education was among the most frequently highlighted priorities of the resettlement administrators. A report by the officer overseeing the entire regroupement program, General Georges Parlange, in August 1960 reckoned that 193,612 boys and 173,820 girls of school age were in the resettlement camps. Of these, 100,065 boys and 50,177 girls were receiving an education in 2,601 classes run by 1,195 civilian teachers and 1,147 teachers on military service; the school enrollment rate in the camps was reckoned to be 5 percent above the average for rural Algeria as a whole. Taking Parlange's figures at face value, this meant that there were no fewer than sixty-four children to each available teacher, but the limited means available did not prevent the schools program from being considered a major "factor of progress" for Algerian society. ${ }^{63}$ By 1961, slightly less than 40 percent of all school-age Algerian children were in school, and army-run schools taught 10 percent of all primary schoolchildren. But even with this ramped-up deployment of resources in the countryside, the increase in educational provision between 1955 and 1962 was smaller than that achieved between 1945 and 1954.

${ }^{60}$ Photographs accompanying report, by Cpt. Bogros, El Meridj, October 7, 1959, $\mathrm{FR} / \mathrm{CADN} / \mathrm{Alg} / \mathrm{Amb}(\mathrm{DG}) / 51 / 3$.

${ }^{61}$ Bogros, "La révolution communale," 12.

62 "Note relative au regroupement de Bou Maiza (Commune d'Aïn Nechma, Arrondissement de Bône)," n.d. [1959] (4 pp.); "Monographie du Centre de Bou Maïza," n.d. [1959]; and Cpt. Seys, officer commanding SAS Bou Maïza, to Colonel commanding with rank of Sub-Prefect, Arrondissement of Bône, June 5, 1959, with photographs attached, FR/CADN/Alg/Amb(DG)/51/4.

${ }^{63}$ Gen. Parlange, "Contribution de l'Inspection générale des regroupements au rapport d'information générale," Algiers, August 13, 1960, quotes at 9, 11, FR/CADN/Alg $/ \mathrm{Amb}(\mathrm{DG}) / 51 / 6$. As civil and military commandant of the Aurès-Nementchas region (one of the early centers of the FLN's insurrection) from May 1955, Parlange was the initiator of the first resettlement centers, which were created to house the people removed from militarized "forbidden zones" in the mountains. 


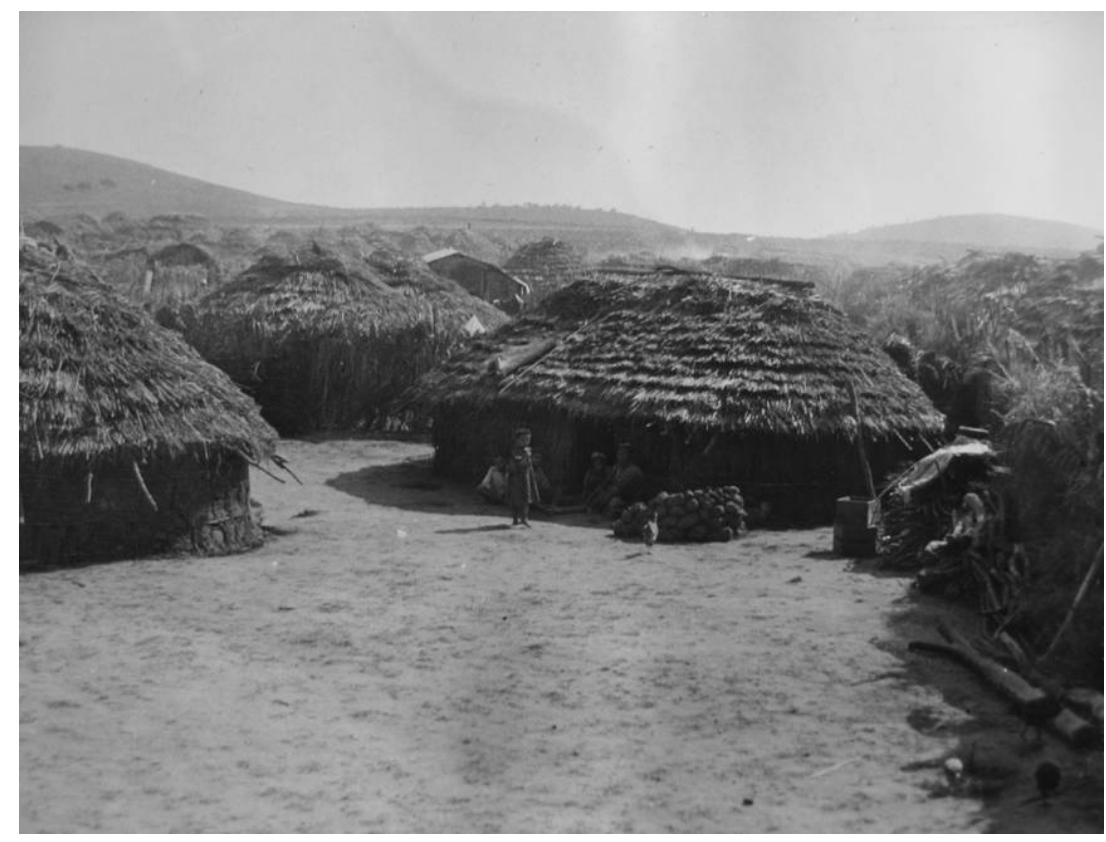

FIG. 1.-Resettlement camp at Bou Maïza, eastern Algeria, 1959. Archives du ministère des Affaires étrangères, Nantes, Alger, ambassade, 21PO/A/52, dossier 4.

As Hartmut Elsenhans concluded, in rural areas "resources were actually applied on so small a scale as to make it manifestly impossible to achieve any real success, in terms of greater capacity and will to integrate the rural population, before the end of the war." 64

A yet more striking disjuncture between the ambitions of development and the realities of resettlement is apparent in a comparison of the imagined material environment of the camps - as, for example, in the architect's drawing for the proposed new village of Bou Maiza (fig. 2) — with images showing what completed resettlement villages more normally looked like - as, for instance, at Ouled Bu Djemaa in western Algeria (fig. 3). In August 1960, this "new village" housed 1,240 people and boasted a prefabricated school as well as a "Roman" rectilinear plan around a parade ground and guard towers at the corners commanding its central axis. ${ }^{65}$ Echoing an older colonial trope of France as the

${ }^{64}$ Hartmut Elsenhans, La guerre d'Algérie, 1954-1962: La transition d'une France à une autre. Le passage de la IVè à la Vè République (Aix-en-Provence, 1999), 710-21, quote at 719 .

${ }^{65}$ Note on Ouled Bu Djemaa resettlement, with photograph, annexed to Parlange, “Contribution," FR/CADN/Alg/Amb(DG)/51/6. 


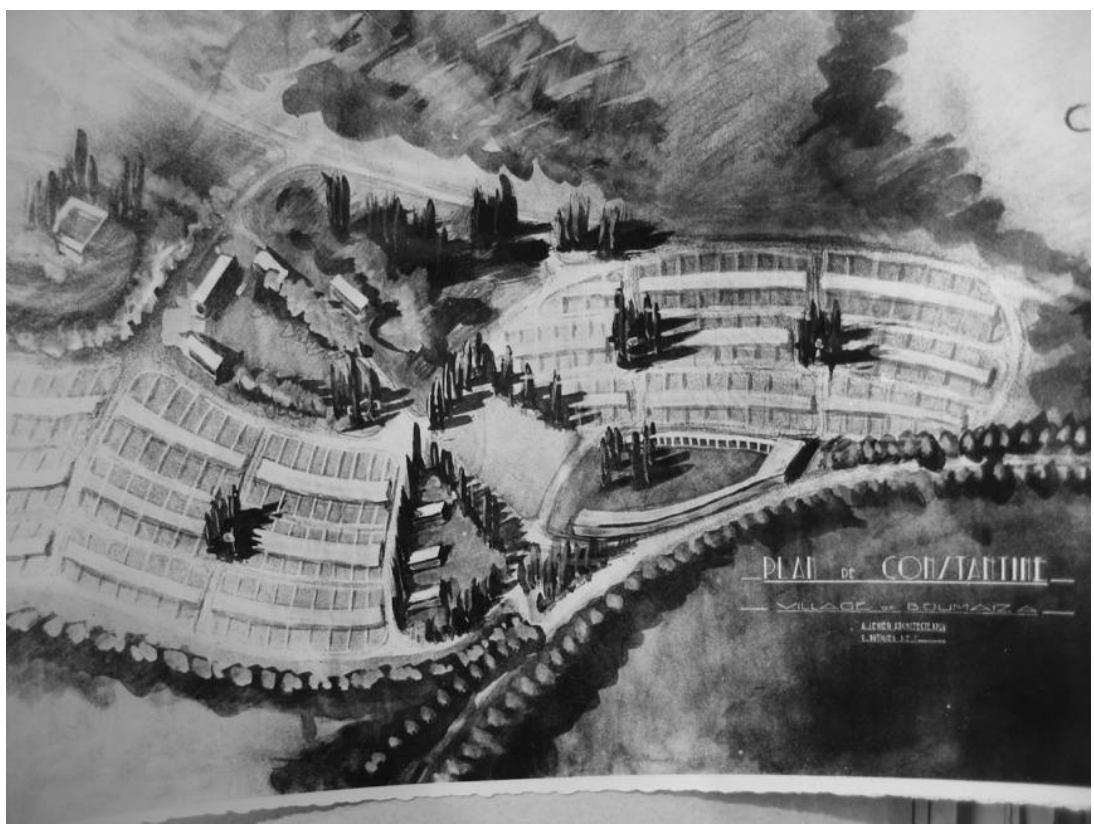

FIG. 2.-Architect's sketch for the projected "new village," Bou Maïza. Archives du ministère des Affaires étrangères, Nantes, Alger, ambassade, 21PO/A/52, dossier 4.

heir to Western Mediterranean empire building in "Latin Africa," references to Roman precedents - in irrigation, urbanism, and North African development as a whole-were quite frequently invoked in writing on the Constantine Plan. Parlange, however, noted the resettled populations' reactions against quadrilateral plans, "the fashion for which derives from Africa's Roman settlements," with the comment that "a more intimate, clustered arrangement is preferred to this by the peasants coming down from the mountains." ${ }^{66}$ One suspects that the peasants' own conceptions of their security may not have been irrelevant to the preference. A photograph of El Ouennane, the "village de l'Ain" in the plain south of Arzew, taken while the permanent resettlement was under construction between March and December 1960 (fig. 4) similarly shows the lots being built along neat, straight roads, radiating at acute angles from the watchful windows of the guard tower at their intersection.

This was the reality of the promise of citizenship and modernization, as actually experienced by millions of Algerians at the frenetic end of colonial rule. The revolution of rights and inclusion was inseparable from containment by

${ }^{66}$ Parlange, "Contribution,” 9, FR/CADN/Alg/Amb(DG)/51/6. 


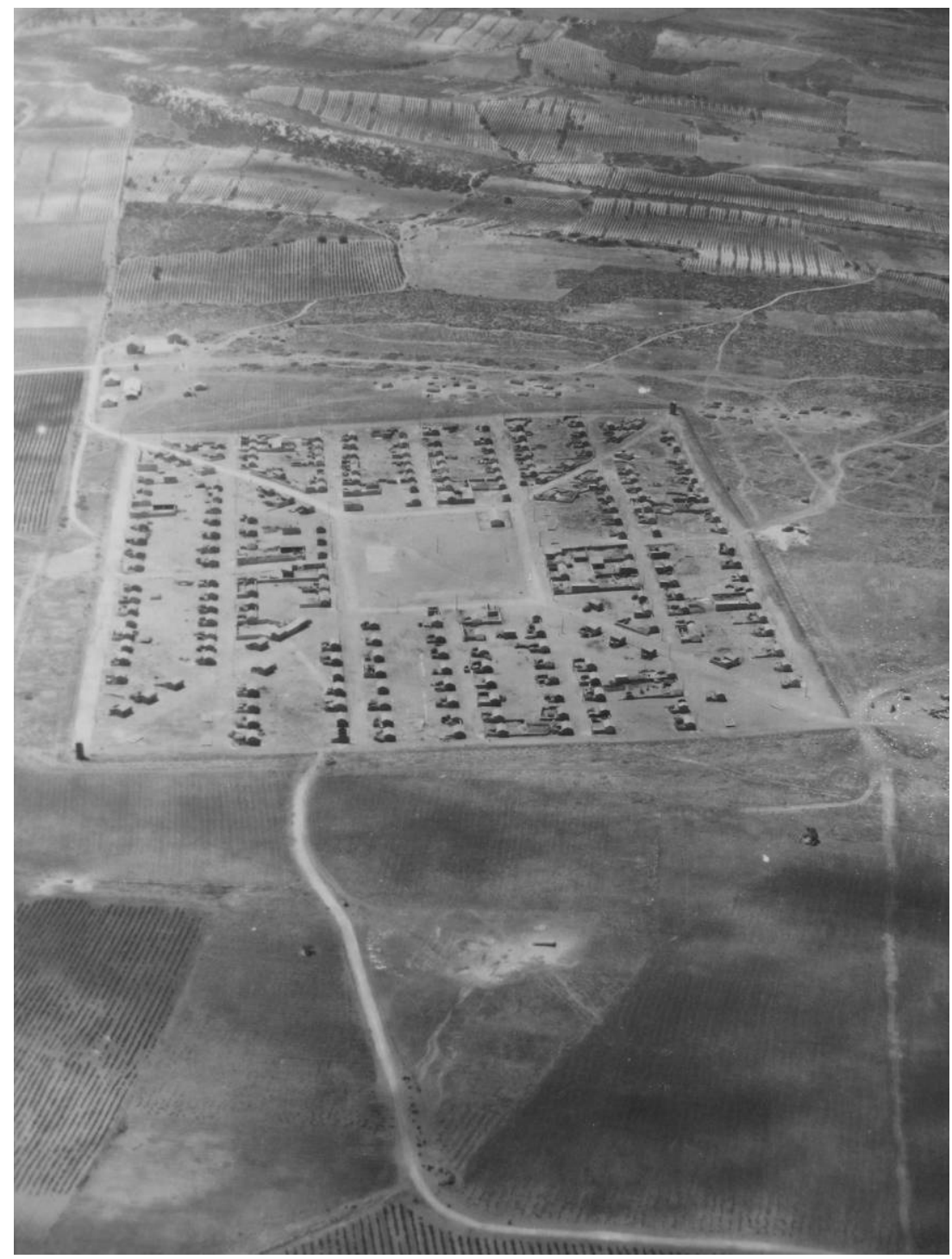

FIG. 3.-Aerial photograph of a completed resettlement village, Ouled Bou Djemaa, western Algeria, 1960. Archives du ministère des Affaires étrangères, Nantes, Alger, ambassade, 21PO/A/51, dossier 6.

This content downloaded from 163.001.203.245 on September 25, 2019 02:20:40 AM All use subject to University of Chicago Press Terms and Conditions (http://www.journals.uchicago.edu/t-and-c). 


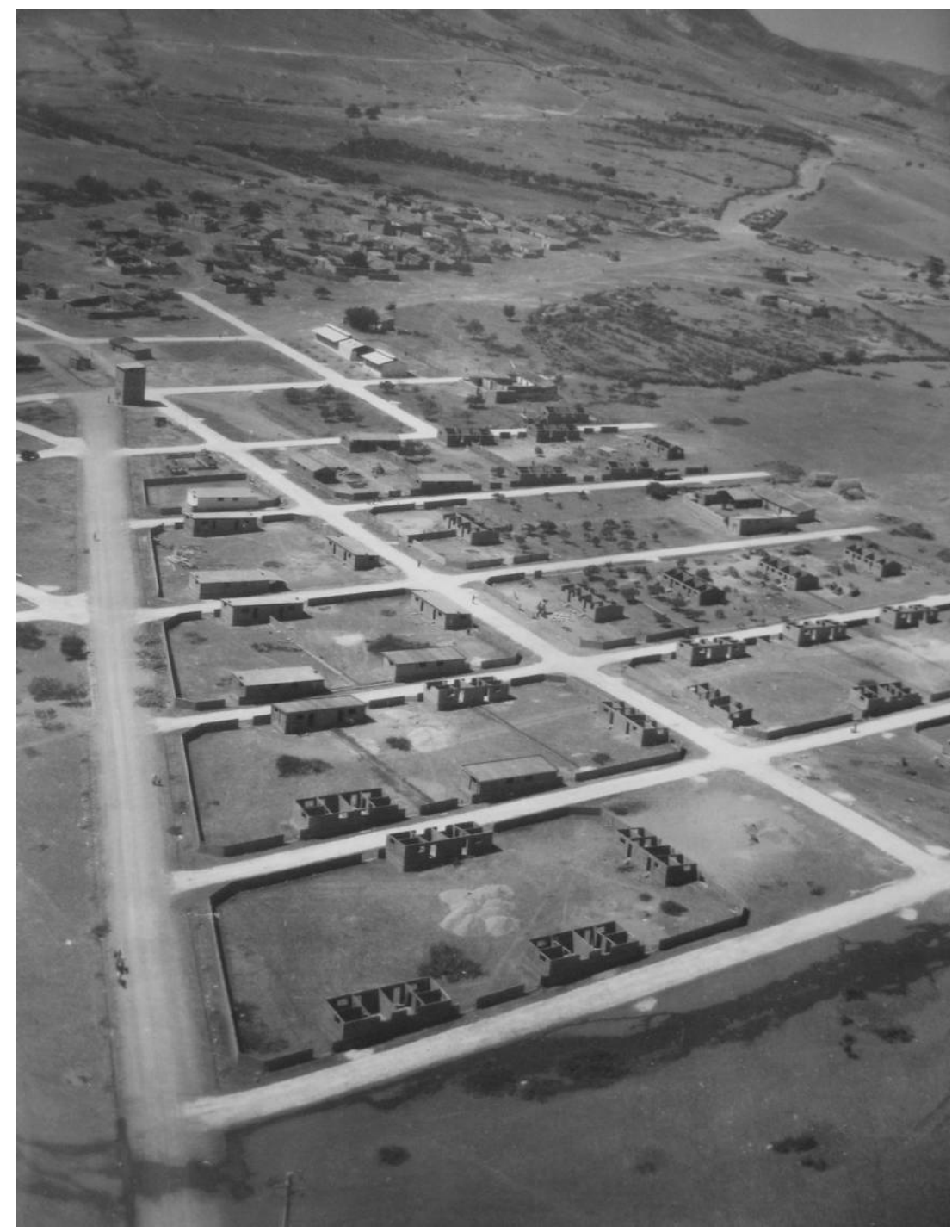

FIG. 4.-Aerial photograph of the new village at El Ouennane ("village de l'Ain"), under construction, 1960. Archives du ministère des Affaires étrangères, Nantes, Alger, ambassade, 21PO/A/51, dossier 6 .

This content downloaded from 163.001.203.245 on September 25, 2019 02:20:40 AM All use subject to University of Chicago Press Terms and Conditions (http://www.journals.uchicago.edu/t-and-c). 
counterinsurgency. Access to the "civilization of the twentieth century" 67 was indistinguishable from submission to a "second conquest" - of their land and of themselves.

\section{Conclusion}

In November 1961, only four months before the ceasefire that ended France's last, disastrous colonial war, the ongoing program of development began to publicize its achievements around the Algerian countryside with a traveling exhibition on the Constantine plan: a massive tent was sent to tour "the mountains and the plains," inviting Algerians to enter its three "gates of progress," which were marked "renovate the countryside," "educate men," and "create a modern industry." These three gates to the future were to show Algerian peasants the way "to a new Algeria which is becoming more real every day." ${ }^{\prime 68}$ Algerians' experience of this late publicity drive for the Franco-Algerian future must surely have been somewhat akin to their experiences of the many other state-sponsored ceremonies that had been taking place over the previous years, such as that photographed for the administration sometime in 1959 at Ait Bouaddou in the high Djurdjura mountains in Kabylia, south of the administrative center of Tizi Ouzou (fig. 5). It is, of course, difficult to evaluate exactly the effect of such events, which were part of a sustained and extensive series of propaganda exercises aimed at "winning hearts and minds" among the Algerian population, ${ }^{69}$ but the

${ }^{67}$ Moritz Feichtinger and Stephan Malinowski, "Eine Million Algerier lernen im 20. Jahrhundert zu leben: Umsiedlungslager und Zwangsmodernisierung im Algerienkrieg, 1954-1962," Journal of Modern European History 8, no. 1 (2010): 107-35.

${ }^{68}$ Bulletin de la CEDA, no. 12 (1962), 37-38.

${ }^{69}$ For discussions, see Daniel Lefeuvre, "Les réactions algériennes à la propagande économique pendant la guerre d'Algérie," in La guerre d'Algérie et les Algériens, 19541962, ed. Charles-Robert Ageron (Paris, 1997), 231-44; and Neil MacMaster, "The 'Silent Native': Attentisme, Being Compromised, and Banal Terror during the Algerian War of Independence, 1954-62," in The French Colonial Mind, vol. 2., Violence, Military Encounters, and Colonialism, ed. Martin Thomas (Lincoln, NE, 2011), chap. 11. Suggestive indications can be found in the documents edited by Mohamed Harbi and Gilbert Meynier (Le FLN: Documents et histoire [Paris, 2004], pt. 3) and in the compendium of testimonies published by the engagés journalists Patrick Kessel and Giovanni Pirelli (Le peuple algérien et la guerre: Lettres et témoignages d'Algériens [Paris, 1962]). The diary of novelist and schoolteacher Mouloud Feraoun (Journal, 1955-1962 [Paris, 1962]) is an unequaled source for personal reflection and comments on public opinion before the writer's own assassination in March 1962. It is of course possible that in some cases responses were more positive, but it is clear that the weapons of such psychological warfare were exceedingly blunt. Indications of the reasons for "rallying" to France in the oral testimonies of harkis invoke ambient confusion, insecurity, lack of clear alternatives, and the fear of being caught in cycles of reprisal rather than "loyalty" or the effect of pro-French propaganda. ("Récits de vie de harkis," oral history archive held at the 


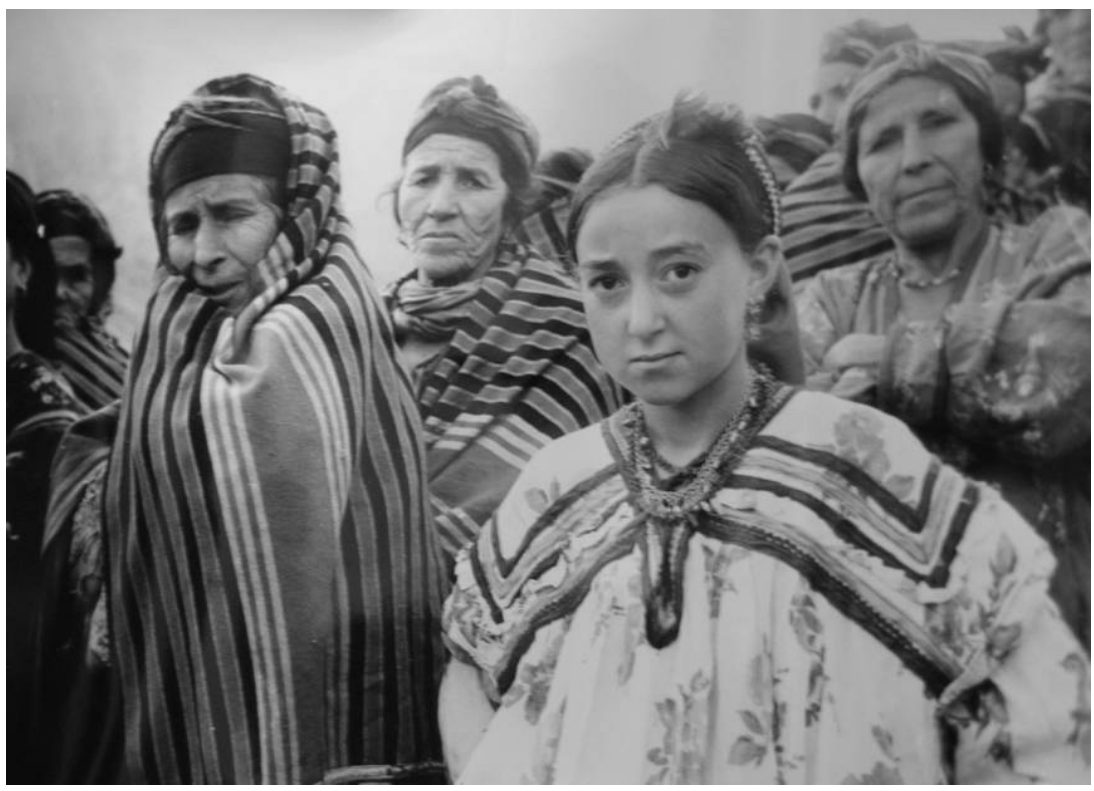

FIG. 5.-Women and children assembled for an official visit, Aït Bouaddou, Kabylia, 1959. Photograph by Jacques Bender. Archives du ministère des Affaires étrangères, Nantes, Alger, ambassade, 21PO/A/52, dossier 3.

photographic record preserved in the French archives shows us women and younger children lined up in their best dresses, their expressions anxious, guarded, or dutiful; children crowded three to a desk in a shiny new schoolroom, benignly observed by men in suits and uniforms; assembled men addressed from on high by officers tracing out the "road to the future."

How different was this, really, to the ceremony held on May 24, 1958 (fig. 6), at Lamartine near Orléansville (today's Chlef, in the Cheliff valley further west) - a former FLN stronghold "pacified" by the French army, where Algerian women were gathered and photographed by the Associated Press taking an "oath to France"? ${ }^{71}$ How different, indeed, was any of it to the ceremony held on May 22, 1945, at Les Falaises on the coast east of Bejaïa, north of Sétif and a little way northeast of Ait Bouaddou, in the aftermath of the insurrection

library-phonothèque of the Maison méditerranéenne des Sciences de l'Homme, Aix-enProvence, consulted courtesy of Gregor Mathias.)

${ }^{70}$ Photographs by Jacques Bender of inspection visit to Ait Bouaddou, FR/CADN $/ \mathrm{Alg} / \mathrm{Amb}(\mathrm{DG}) / 52 / 3$.

71 "Arab women taking the oath to France, May 24, 1958, at Lamartine near Orleansville, which was a former terrorist area." Associated Press photograph (anon.), neg. number 78165. AP digital archive, image ID 580524080. 


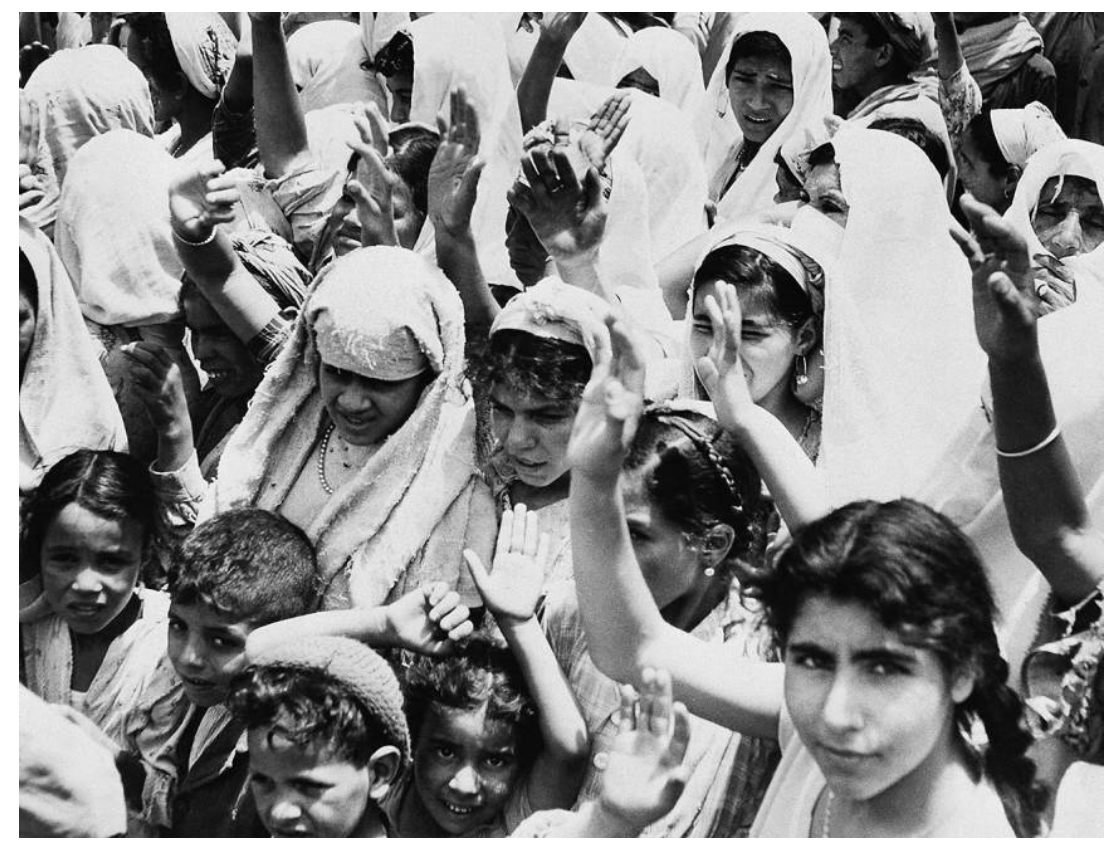

FIG. 6.-Women assembled to take an "oath to France," Lamartine (western-central Algeria), May 24, 1958. Press Association Images.

and cataclysmic repression that had unfolded across the north Constantine region earlier that month? At Les Falaises, the French army orchestrated a mass surrender ceremony to mark the end of hostilities and the "reestablishment of order," for which some fifteen thousand people from the surrounding mountains, "notably women and children," according to a military report on the event, were rounded up to "make their submission" to France in plain sight of a massive display of the military, naval, and air power that over the past two weeks had burned, shelled, and bombed their villages (fig. 7).$^{72}$ Displays of the grandiose schemes of investment and modernization, emancipation and reform that were supposed to announce the "new Algeria" of late 1961 may have been consciously intended as deliberately unlike the archaic ceremonial of collective popular submission enacted fifteen years earlier, but both were unavoidably, inextricably part of the same process of colonial reconquest whose dénouement was also its apogee. As the ceremonial of surrender in 1945 marked the beginning of the postwar

72 10th Military Region General Staff, 2ème bureau, "L'Insurrection de la Petite Kabylie (8 au 22 mai 1945): Documents photographiques" (24 pp., report with photographs), FR/CADN/Alg/Amb(DG)/51/1. 


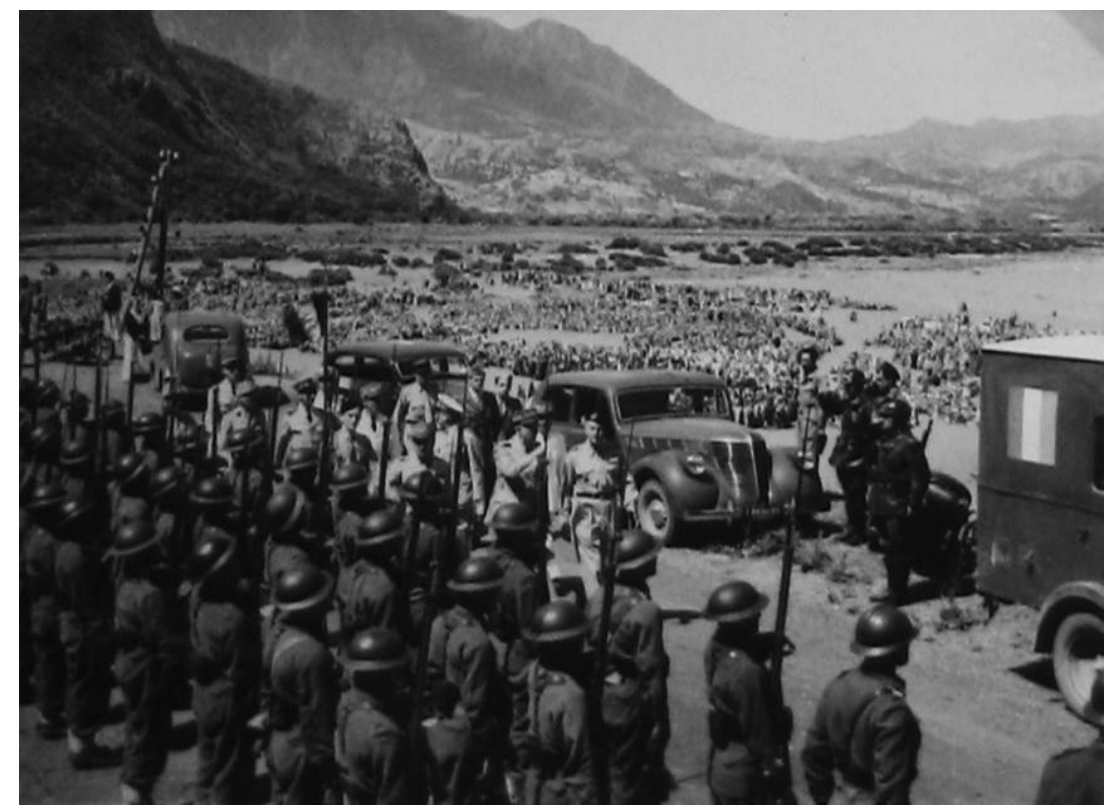

FIG. 7.-Les Falaises, May 22, 1945. Troops in the foreground on the coast road; assembled Algerian civilians on the beach in background. Archives du ministère des Affaires étrangères, Nantes, Alger, ambassade, 21PO/A/51, dossier 1.

reinvention and reassertion of empire, that of promised victory and renewal in 1960-61 at places like the "village de l'Ain" repeated the same script in a mode that may in hindsight seem farcical but that was nonetheless tragic. Both kinds of ceremony were demonstrations of the imperial Republic's continued, and indeed expanded, reliance on the rule of force, even as it proclaimed, and indeed expanded, the liberalism of its law.

For France to be decolonized - for the unrepublican regimes of exception within the trans-Mediterranean polity to disappear and for a normalized rule of law to take their place-Algeria, beaten into submission since the mid-nineteenth century but never truly "integrated," had to be reconquered, its territory and its population incorporated as they never, in fact, had been before into the sovereignty of the (post)imperial Republic. This was the "revolution" imagined by French soldiers, politicians, and technocrats as the fullest achievement of the republican universalism long claimed as the heart of France's global and national vocation. At the same time, of course, a very different Algeria, a country older than the one the French imagined they had themselves created and a nation newer than its ideologues believed, was being forced through the painful, and properly revolutionary, process of emancipation from the straitjacket of colonial rule by 

Algerians forging their own state as their own means of self-determination and
development. The glaring antinomies of liberal-colonial conquest, with which
they were more than sufficiently familiar, were none of their concern. For post-
imperial France, on the other hand, it would be a long time before the grotesque
paradoxes of empire's end could be seen for what they were; reinventing the post-
imperial Republic, with its common citizenship and multiple cultures, would re-
main a challenge for more than a half century to come. 